\title{
Biologia Futura: integrating freshwater ecosystem health in water resources management
}

\author{
Janos J. Bogardi ${ }^{1}\left[\right.$ ] Jan Leentvaar ${ }^{2} \cdot$ Zita Sebesvári $^{3}$
}

Received: 17 February 2020 / Accepted: 20 July 2020 / Published online: 5 August 2020

(c) The Author(s) 2020

\begin{abstract}
Sustainable water use implies the simultaneous protection of water quality and quantity. Beyond their function to support human needs such as drinking water provision, transportation and recreation freshwater bodies are also habitats. Conceiving them as water users on their own with respective biological, physico-chemical and morphological requirements could help maintaining their healthy state. Healthy freshwater ecosystems are also attractive for high-value human uses. Dwindling per capita availability of water, increasing demands, human well-being and climate change lead to competition for, and pressures on freshwater ecosystems. This has been conceptualized through the modification of the drivers-pressures-stateimpacts-responses framework. This distinguishes between pressures, associated with the achievement of human well-being, and stressors, which are defined as the negative effect of excessive pressures or combination thereof on aquatic ecosystems. Guidelines usually specify threshold values to classify water bodies as appropriate for certain utilitarian uses. However, only few guidelines focus on freshwater ecosystem health. Eight guidelines for monitoring of freshwater ecosystem health were analysed in the UNEP-funded project "International Water Quality Guidelines for Ecosystems". Based on this review, general benchmark values are proposed for key physico-chemical indicators. Furthermore, adaptive pathways towards improved monitoring and protection of the health of freshwater ecosystems are recommended. In this paper, we review the main findings of the report and also review its recent uptake. Water quality guidelines for freshwater ecosystems cannot be conceived without societal consensus and vision. Different climatic, geographical and socioeconomic contexts are to be considered too. Their development is embedded in an adaptive cycle. Its multiple phases and steps indicate a long-term approach including reassessment and potential revisions.
\end{abstract}

Keywords Water challenges $\cdot$ Stressors of freshwater bodies $\cdot$ Modified DPSIR $\cdot$ Water quality guidelines and benchmarks

Electronic supplementary material The online version of this article (https://doi.org/10.1007/s42977-020-00031-7) contains supplementary material, which is available to authorized users.

\section{Janos J. Bogardi}

jbogardi@uni-bonn.de

Jan Leentvaar

jan@leentvaar.org

Zita Sebesvári

sebesvari@ehs.unu.edu

1 Institute of Advanced Studies (iASK), Chernel utca 14, Köszeg 9730, Hungary

2 IHE Delft Institute for Water Education, Westvest 7, 2611 AX Delft, The Netherlands

3 United Nations University Institute for Environment and Human Security (UNU-EHS), Platz der Vereinten Nationen 1, 53113 Bonn, Germany

\section{Introduction}

\section{Water challenges at the beginning of the twenty-first century and the framework to address them}

Population growth, economic development, land use/land cover as well as climate change imply growing pressures on the quality and quantity of water resources and on the respective aquatic ecosystems. Declining water quality has major consequences for human, but also for ecosystem health and for the biodiversity of these ecosystems (Butchart et al. 2010). In this paper, the term "water quality" is used in a very general sense. While freshwater ecosystem health covers, and integrates, the physical, chemical, biological and hydromorphological dimensions of freshwater ecosystems, good water quality is the main prerequisite and probably 
the most measurable and comparable attribute of ecosystem health of freshwater bodies.

Life on Earth depends on the integrity of ecosystems for their well-being and survival (Lindenmayer and Likens 2010). Yet, this integrity is very much at threat. Economic growth and increasing living standards characterize many countries. Correspondingly, increasing amount of sewage and other wastes are discharged into aquatic ecosystems. While in high-income countries about $70 \%$ of the municipal and industrial wastewater is treated, this drops to 38,28 and $8 \%$ in upper-middle-income, lower-middle-income and low-income countries, respectively (WWAP 2017). These recent numbers support earlier estimates that $80-90 \%$ of all wastewater in developing countries is discharged untreated into rivers, lakes and/or oceans. Already in 2010 two publications "Sick Water?" (Corcoran et al. 2010) and "Clearing the Waters" (Palaniappan et al. 2010) summarized the inherent challenges. Besides direct pollution, indirect pollution leads to an excess of nutrients in water bodies. For example, human interference with the nitrogen cycle represents one of the challenges as far as the respective planetary boundary is concerned (Rockström et al. 2009). Furthermore, it compromises water security for humans and nature (Dudgeon et al. 2006; Vörösmarty et al. 2010). Pesticides, hormones, pharmaceutical residues, other new chemicals and microplastics are emerging pollutants creating new water quality challenges. Therefore, the issue requires global attention and action, as highlighted in the Policy Brief on Water Quality (UN-Water 2011). Even unintended impacts to ecosystems through water uses which rely on good quality water (like withdrawals for human water supply, etc.) are contrary to the aspirations of a sustainable water future as stipulated by the dedicated Water Goal (no. 6) of the Sustainable Development Goals (SDGs) (UNGA 2015). Thus, the consideration of sustainable health of freshwater bodies as ecosystems should also be in the centre of the water agenda instead of the hitherto overwhelming utilitarian focus. Therefore, freshwater ecosystem health is prerequisite to SDGs related to water.

Two targets (6.3 and 6.6) of SDG 6 are explicitly addressing freshwater ecosystem-related objectives, but also the remaining six targets of SDG 6 as well as targets 15.1, 15.5 and 11.5 show the broad relevance of ecosystem health of freshwater systems in achieving the SDGs.

It is important to note that ecosystem protection and rehabilitation targets were set to be achieved by 2020 rather than 2030 (targets 6.6, but also 15.1) as they were aligned with the targets and deadlines stipulated by the Aichi Biodiversity Targets of Strategic Plan for Biodiversity 2011-2020 of the UN Convention for Biodiversity (UNCBD 2011). No doubt healthy freshwater ecosystems facilitate the achievements of other water-related but also health, nutritional and other targets of the SDGs (UNGA 2015). However, we are already off the track to achieve SDG 6 including unfulfilled targets like the rehabilitation of aquatic ecosystems by 2020 (UNWater 2018).

Investments in the protection of water resources and, where necessary, restoration to improve the condition of degraded systems must be undertaken as part of an adaptive process. This process is underpinned by an agreed set of objectives. Monitoring and evaluation is an essential element of the adaptive management process that is required to ensure that management interventions are successful and environmental objectives are met. However, implementation and success control of applied measures is not possible without political will. In this respect, a fundamental paradigm change is needed to strengthen the ecological and societal parts of sustainability versus the hitherto practiced primacy of the economic dimension.

\section{Freshwater ecosystems: the fundament of sustainability}

Biodiversity is widely regarded as an implicit measure to indicate the integrity and healthy functioning of ecosystems. Freshwater biodiversity is in serious decline (Dudgeon et al. 2006; Strayer and Dudgeon 2010). While freshwater ecosystems contain a disproportionately high biodiversity compared to most terrestrial systems, irrespective of the limited space they occupy (Tockner 2019), the Millennium Ecosystem Assessment (MEA 2005) and the IPBES Global Assessment (IPBES 2019) revealed that biodiversity decline in freshwater systems is occurring much faster compared to other ecosystem types. Their sustainability is compromised together with their ability to provide, which, generally described as ecosystem services (ES), is similarly in decline. The present rate of annual extinction of all kinds of species (freshwater, terrestrial and marine) can serve as an indicator of biodiversity loss. This is at present more than tenfold higher than the estimated, scientific consensus-based respective planetary boundary (Rockström et al. 2009). The dramatic state of freshwater bodies, as the most vulnerable ecosystems globally, is evident. In addition, ES have been considered as "services for free" for too long without accounting for the needs proper of freshwater ecosystems. Overexploiting freshwater ecosystems without the chance to regenerate themselves has led to massive deteriorations with major consequences for human health, livelihoods and biodiversity.

Deteriorating water quality also affects the quantity of water available for people, as a significant part of the resource can no longer be considered for higher value uses such as drinking water supply.

The coexistence between the needs of ecosystems and those of human society is central to the concept of environmental flows, which describe "the quantity, timing and 
quality of water flows required to sustain freshwater and estuarine ecosystems and the human livelihoods and wellbeing that depend on these ecosystems" (Brisbane Declaration 2007; Matthews et al. 2014). It has also prompted increased attention to the need for far greater alignment in the future between the processes of environmental flow assessment and the setting of water quality standards for aquatic ecosystems.

Where financial resources are available, considerable investments in catchment protection and restoration, in water quality improvements (Zhang and Wen 2008) and in environmental flow provisions (Tharme 2003; Poff et al. 2010) have been made to reduce the risks to freshwater ecosystems and to protect drinking water sources. However, for countries which may still have the choice, a more precautionary and cost-effective approach would be required to identify and tackle the potential causes of degradation at their source rather than repeating the mistakes which led to major pollution of freshwater bodies, especially in developed countries (Vörösmarty et al. 2010). As prevention is usually more effective and considerably less expensive than remedial actions, continuing to follow the paradigm "impair and then repair" (Vörösmarty 2013), which characterized hitherto the water resources development, is neither wise nor sustainable.

\section{Freshwater ecosystems: general indicators of ecosystem health}

Water quality, biological and hydromorphological conditions of freshwater bodies do not only characterize the status of freshwater ecosystems per se, but reflect the prevailing situation in neighbouring terrestrial ecosystems and the interactions between them as well (Allan 2004). As ultimate sinks in the landscape (through surface run-off and exchanges with groundwater bodies), freshwater ecosystems are excellent proxies to characterize the ecological health of entire river basins.

Utilitarian water quality guidelines (WQGs) classify water bodies according to the degree to which they can appropriately serve as a basis for human use, such as drinking water, ${ }^{1}$ recreational use, ${ }^{2}$ irrigation, ${ }^{3}$ livestock ${ }^{4}$ and water reuse. ${ }^{5}$ Such guidelines and their supporting standards were established and subsequently embedded in national and

\footnotetext{
${ }^{1}$ http://www.who.int/water_sanitation_health/dwq/guidelines/en/.

2 http://www.who.int/water_sanitation_health/bathing/srwe1/en/.

3 http://www.oecd.org/tad/sustainable-agriculture/waterqualityand agriculturemeetingthepolicychallenge.htm.

${ }^{4}$ http://www.fao.org/DOCReP/003/T0234e/T0234E08.htm; http:// eur-lex.europa.eu/legal-content/EN/TXT/?uri=CELEX\%3A319 91L0676.

5 http://ec.europa.eu/environment/water/reuse.htm; http://www.unep. or.jp/Ietc/Publications/Water_Sanitation/wastewater_reuse/.
}

international contexts during the twentieth century (e.g. Ayers and Westcot 1985; DeZuane 1997; WHO 2011). Comparable WQGs for ecosystems with a focus on ecosystem health of inland waters are still rare. These WQGs would provide an appropriate framework and basis for the remediation and monitoring of water bodies, towards freshwater ecosystem health and function, including the provision of ecosystem services (ES). WQGs and selected indicators will be important to assess whether countries are meeting the SDG targets 6.3, 6.6 and 15.1 set for the protection of freshwater ecosystems and the reduction of water pollution. Water quality standards for freshwater ecosystems consider ecosystems as "users" like other water use sectors with the right of water withdrawal, or in situ use. Next to their function as resource base, this attribute of freshwater ecosystems as "water user" with certain quantitative and qualitative requirements facilitates the integration of an ecosystem-based approach into water resources management.

As a primary instrument to guide and to monitor sustainable restoration/rehabilitation actions and environmental safeguards, water quality standards for ecosystems are necessary. For this reason, the consideration of "traditional" physicochemical water quality indicators is to be extended to include biological and hydromorphological indicators to provide a more comprehensive assessment of freshwater ecosystem health. Since this increases monitoring complexity, biotic indicators have become a core component of freshwater ecosystem health assessment since they respond to and indicate the overall water quality regardless of the type of pressure and stressor over longer time spans. To date, biotic indicators have been especially integrated in freshwater assessment in the developed world (e.g. Wright 1995; Schofield and Davies 1996; Rosenberg et al. 1997; Barbour et al. 1999; Hering et al. 2010), but also increasingly in emerging economies and developing countries for instance in South Africa (DWAF 1996).

It is worth noting that the inclusion of biotic indicators also helps to assess the risks to water quality and has the added advantage that freshwater organisms are continuously exposed to stressors and therefore provide information over both long-term, but also sporadically occurring stressors.

This paper is based on the scientific report International Water Quality Guidelines for Ecosystems (IWQGES) prepared in 2012-2016 as basis of the UN Environment published "A Framework for Freshwater Ecosystem Management" (FFEM) (UNEnvironment 2018). Being available as a report and missing from the scientific literature, its potential use by the scientific community would remain limited. Our aim was to review the main findings of the report and its recent uptakes for the academic community.

Four particular aspects, (1) the nexus of human wellbeing and freshwater ecosystem health, (2) the distinction and interactions between pressures and stressors of 


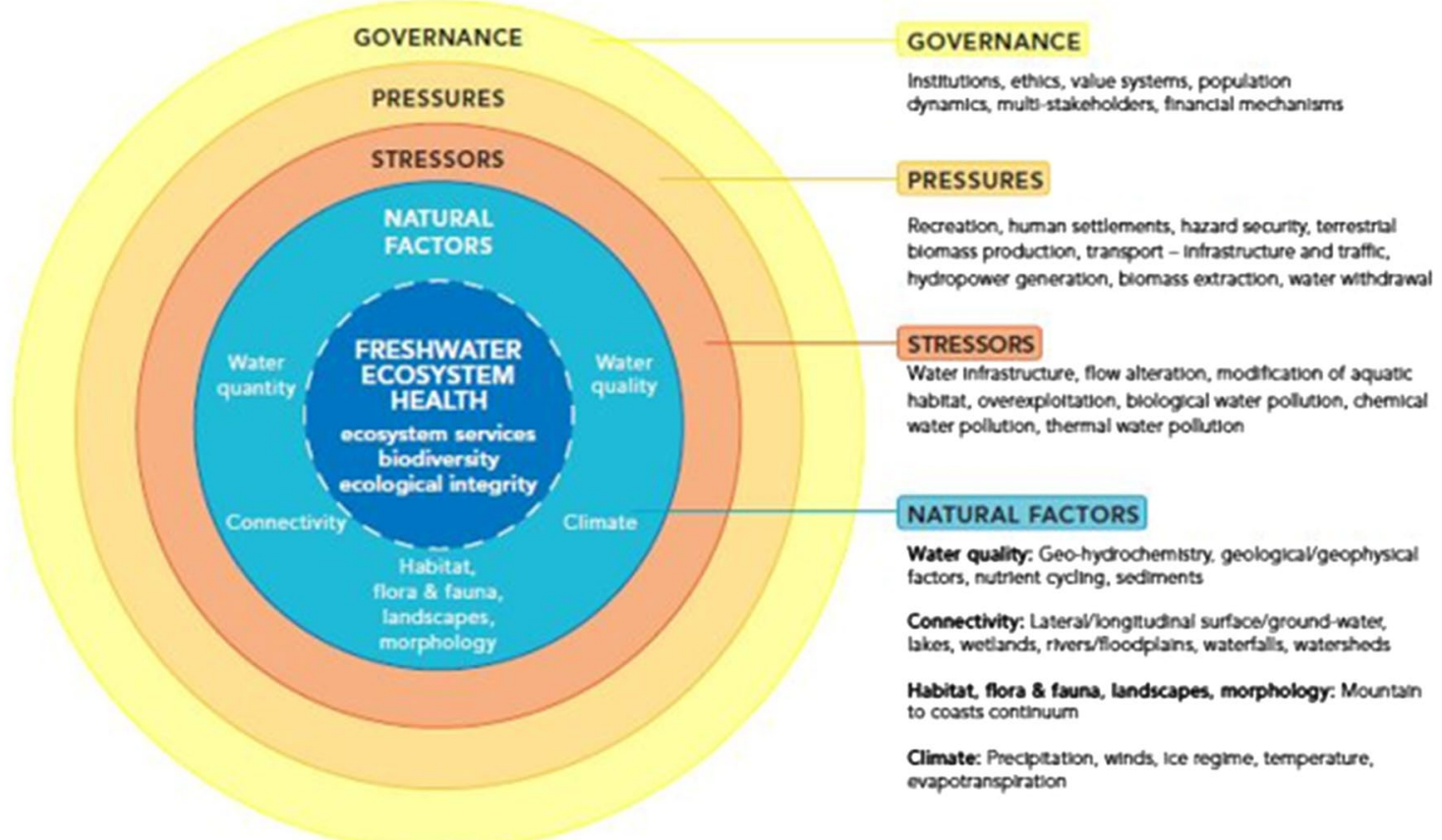

Fig. 1 The conceptual framework of the socioecological system with freshwater ecosystem health in its centre. Source: UN Environment (2018) A Framework for Freshwater Ecosystem Management. Volume 4: Scientific Background

freshwater water bodies, (3) the proposed iterative adaptive frame to develop water quality guidelines for freshwater ecosystems and (4) the set of recommended benchmarks to delimit the ranges of good and unacceptable water quality status of freshwater ecosystems will be discussed.

\section{The nexus of human well-being and freshwater ecosystem health}

Aquatic ecosystems are providing natural resources (among them fish and clean water are the primary ones), transportation, energy, dilution of pollutants and recreation (Naiman and Bilby 1998). As a result, very complex inter-relationships between socioeconomic factors and the hydrological and ecological conditions of freshwater bodies have developed. Freshwaters need to be considered as part of coupled social-ecological systems where human benefits and ecosystem health cannot be treated in isolation. As a consequence of this close relationship, the integrity of aquatic ecosystems is often challenged (Bartram and Balance 1996; US EPA 2006).

Consequently, the inter-relationships between water and society should be modelled in one comprehensive concept of socioecological systems as exemplified in Fig. 1.

Due to their prominent role as basis for the societal development, inland waters are among the most altered ecosystems in the world. More than two-thirds of all large rivers are fragmented; reservoirs trap more than $25 \%$ of the total sediment load that formerly reached the oceans (Vörösmarty and Sahagian 2000). Out of the estimated $40,000 \mathrm{~km}^{3}$ annual terrestrial water flux (aggregated stream flow and aquifer outflow to the oceans) (Trenberth et al. 2007), approximately $10 \%$ is withdrawn (Rockström et al. 2009). As a global average, around $70 \%$ of all water withdrawn is used for agricultural (mainly irrigation) purposes (Wallace et al. 2003).

Riparian areas and the coastal zone are attractive for human settlements and economic activities. More than $50 \%$ of the global human population lives within $3 \mathrm{~km}$ distance to a water body; less than $10 \%$ of the population lives at a distance greater than $10 \mathrm{~km}$ from a water body (Kummu et al. 2011). For example, in Europe and Japan, about 50\% of the population currently lives on (former) floodplains (Nakamura et al. 2006). River deltas have very fertile soils and are, therefore, among the most populated areas globally (e.g. deltas of the Ganges/Brahmaputra/Meghna, Nile, Rhine, Mekong, Irrawady and Yellow Rivers) (Ericson et al. 2006).

Humans both benefit (as water users) and suffer (i.e. as flood victims) from their interaction with freshwaters. With their measures to increase benefits and to reduce potential losses, they have also profoundly altered inland waters. Inevitably most ecosystems are exposed to multiple humancaused pressures. These led in many cases to stresses including water pollution, flow modification, habitat degradation, overexploitation and introductions of alien species which 
Fig. 2 Linking the societal and freshwater subsystems and their causal chains of links. Source: Modified based on ISTAT, C. Costantino, F. Falcitelli, A. Femia and A. Tuolini (OECD Workshop Paris, May 14-16 2003)

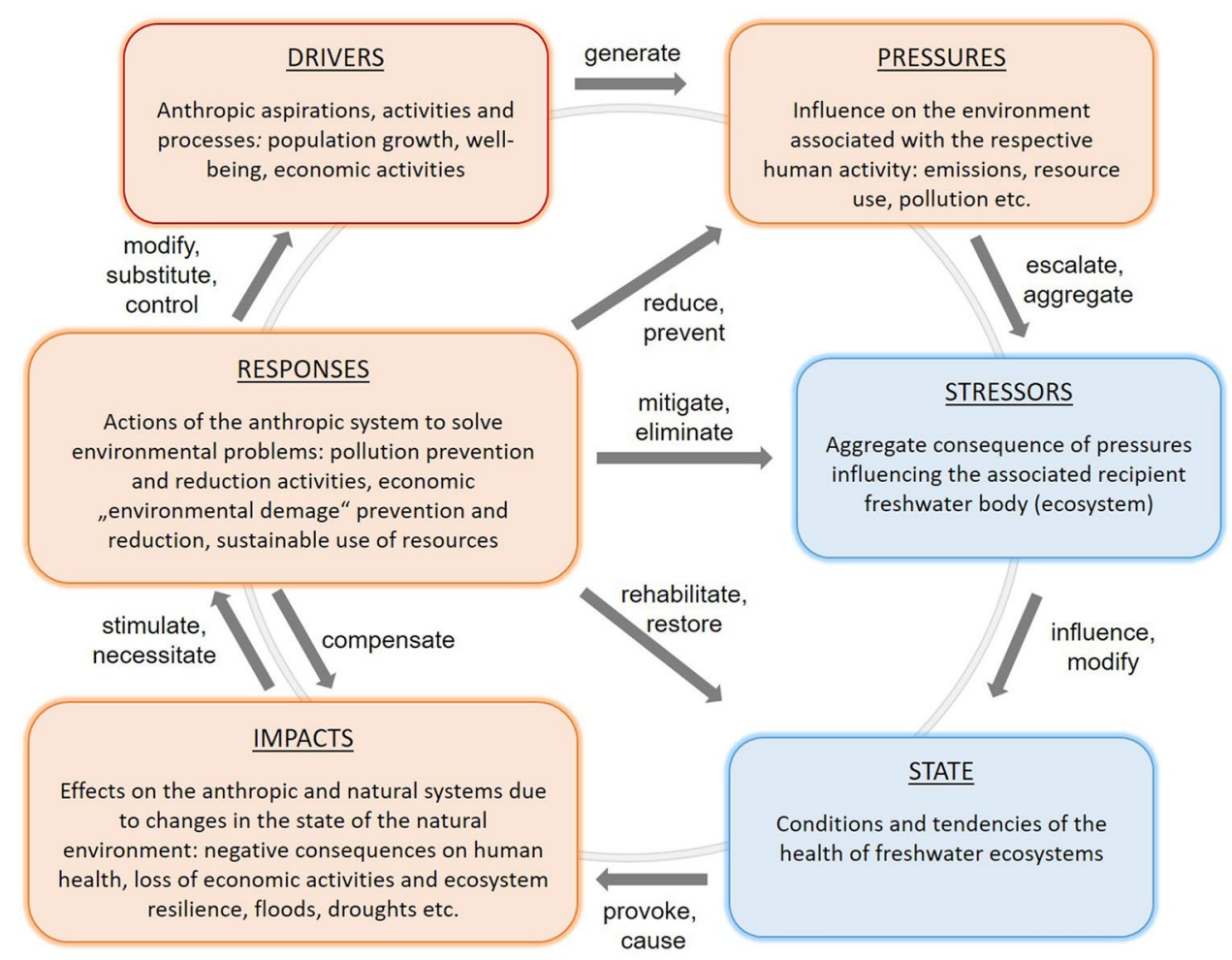

became invasive (Allan and Flecker 1993; Malmqvist and Rundle 2002; Dudgeon et al. 2006).

Increasing pressures on water resources and the resulting stresses, along with a persistent lack of attention to the tight feedbacks between ecosystem functioning and human well-being, have led to an unprecedented deterioration of the hydromorphological, physico-chemical and biological state of freshwater bodies. It is becoming more and more evident that without adequate measures, such as continuously improving wastewater treatment (WWT) schemes, recycling water in closed loops, regulating source-directed control (SDC) measures of pollution and applying innovative and sustainable conservation strategies, many freshwater ecosystems, which still support human well-being, may collapse. Hence, there is an urgent need to establish water quality guidelines (WQGs) that help to define and safeguard healthy and to restore degraded freshwater ecosystems. The key challenge is to manage freshwaters systems as both a critical resource for humans and a highly diverse biotope.

In a world inhabited by more than seven billion people (expected to reach around some 10 billion by 2050), a "humans-outside-nature" approach will simply not work and can even be considered unethical. Without question, aspirations of human well-being (as expressed in the millennium development goals (MDGs) and the sustainable development goals (SDGs), as well as other multilateral agreements) need to be aligned with oftentimes competing environmental objectives. This dual role of meeting the needs of humans and nature has been identified in the SDGs for water (SDG6), with parallel targets set for human wellbeing, pollution control and ecosystem protection (UNGA 2015).

\section{Distinctions and interactions of pressures and stressors}

The well-known drivers, pressures, states, impacts, responses (DPSIR) cycle is proposed to be extended with the additional "stressor" element (thus drivers, pressures, stressors, states, impacts, responses (DPSSIR) model) to emphasize the interface between the societal and freshwater subsystems shown in Fig. 2.

The extent to which anthropocentric activities influence ecosystems and their capability for service provision can best be captured through a drivers, pressures, stressors, states, impacts, responses (DPSSIR)-based assessment (as suggested in this paper and OECD 1993). The driver(s), the aspiration of human well-being, exert inevitable pressures on the supporting ecosystems. Whether or not an ecosystem can cope with these pressures depends on the nature of the pressures, their magnitude, intensity, duration, frequency and interactions and whether they are superimposed to act as stressors. The state of the ecosystem co-determines its capacity to absorb stressors without long-lasting consequences. Healthy and diverse ecosystems are more resilient and therefore attenuate the effect of stressors. 
Pressures are the consequence of human activities seeking to satisfy various dimensions of human well-being. Pressures can, however, reach levels which cannot be compensated by the "natural resilience" of the respective ecosystems. Consequently, their functions are impacted and they start to deviate from their "healthy state". Thus, the pressures become sources of stress. Several pressures may aggregate and cause stress or one type of pressure might cause different kinds of stresses, which are directly relevant for inland surface water bodies. Thus, pressures are conceptualized in association with human use, whereas stressors refer to the water bodies, epitomizing the negative impacts of potentially aggregated effects of pressures to the supporting freshwater ecosystems. This distinction was introduced to account for the "two sides of the coin" of exploiting ecosystem service for (increasing) human well-being.

An illustrative matrix of pressure/stressor relationships is presented in Table 1. The selection of strong or indirect relationships between pressures and stressors is indicative and refers to general conditions. Modifications are possible depending on case-specific situations.

\section{Pressures}

Pressures such as water withdrawals for domestic, industrial, mining, agricultural and energy generation (cooling water) purposes and the subsequent discharge of used (waste) waters, but also fisheries, aquacultures as well as sand, gravel and other mineral removal from rivers and lakes constitute extractive and potentially discharge pressures. Hydropower generation and navigation are typically in situ pressures, while transport infrastructure, traffic, terrestrial biomass production, urbanization and recreation, but also security requirements against water-related hazards, can be classified as riparian/basin-scale pressures. Climate variability and climate change as well as various aerosols and depositions constitute additional, global-scale pressures through the easy connectivity through the atmosphere.

Climate change is an unwanted by-product of activities conceived to increase multiple dimensions of human wellbeing. The 5th IPCC Assessment (2014) had a dedicated chapter on terrestrial and inland water systems. The assessment concludes that direct human impacts such as land use and land cover change, water pollution and water resource development will continue to dominate the threats to most freshwater ecosystems over the next three decades (Settele et al. 2014). Climate change will exacerbate many of these pressures, thus showing how combinations of increasing pressures could contribute to worsen several stressors. Rising water temperatures are likely to lead to shifts in freshwater species distributions and worsen water quality problems, especially in those systems with high anthropogenic nutrient loading (Settele et al. 2014).
Land use alteration and its inherent land cover change are the consequence of multiple human activities along shorelines or within the catchment. They might impede freshwater ecosystems through increased sedimentation, nutrient enrichment, contaminant pollution or hydrological alteration. Agriculture and deforestation are the dominant land use changes globally. Urban land use, while increasing, typically covers a smaller percentage of catchments. Indeed, land use pattern and human density in the catchment often serve as suitable surrogate warning indicators of freshwater conditions, acting as a general index of human disturbance. The proportions of cropland and urban area as well as the state of the riparian zones are probably the most effective proxies reflecting the environmental state of freshwater ecosystems (Bunn et al. 1999; Peterson et al. 2011).

\section{Stressors}

Stressors are understood as concrete and ultimately negative manifestations of pressures on inland waters such as construction of water infrastructure (dams, barrages, sluices, ports, dykes, groins or other types of artificial obstacles within water bodies), alteration of flow and water levels (through withdrawals, discharges, backwater effects, hydropower generation and the operation of water infrastructures), modification of aquatic habitats (dredging, mining, river training), overexploitation of aquatic resources, biological water pollution such as the emergence of invasive alien species but also that of pathogens and genetic modifications in freshwater ecosystems, chemical and thermal pollution (mainly through the discharge of wastewater and returning cooling water).

For example, whether a freshwater body is overexploited (thus exposed to the stressor "overexploitation") depends mainly on aggregate effects of (usually increasing) pressures emanating from various water uses (withdrawal, wastewater discharge), gravel and sand removal, fishing and aquacultures, dense human population (settlements and recreation) and indirectly through climate change as an additional limiting factor of ecosystem resilience. As such, through its increasingly negative consequences, the evolving climate change could also become a "stand alone" stressor, even if freshwater bodies were unaffected by other stressors.

\section{Water infrastructure}

Infrastructure developments including dams, levees, port and harbour infrastructures, bridges and other engineering structures located in or constraining water bodies are usually stressors which modify water flow, lateral and longitudinal connectivity and hydromorphology with potentially harmful effects on freshwater species since they often cannot adapt to these abruptly introduced changes (Allen 
Table 1 Pressures and stressors relevant for inland surface waters

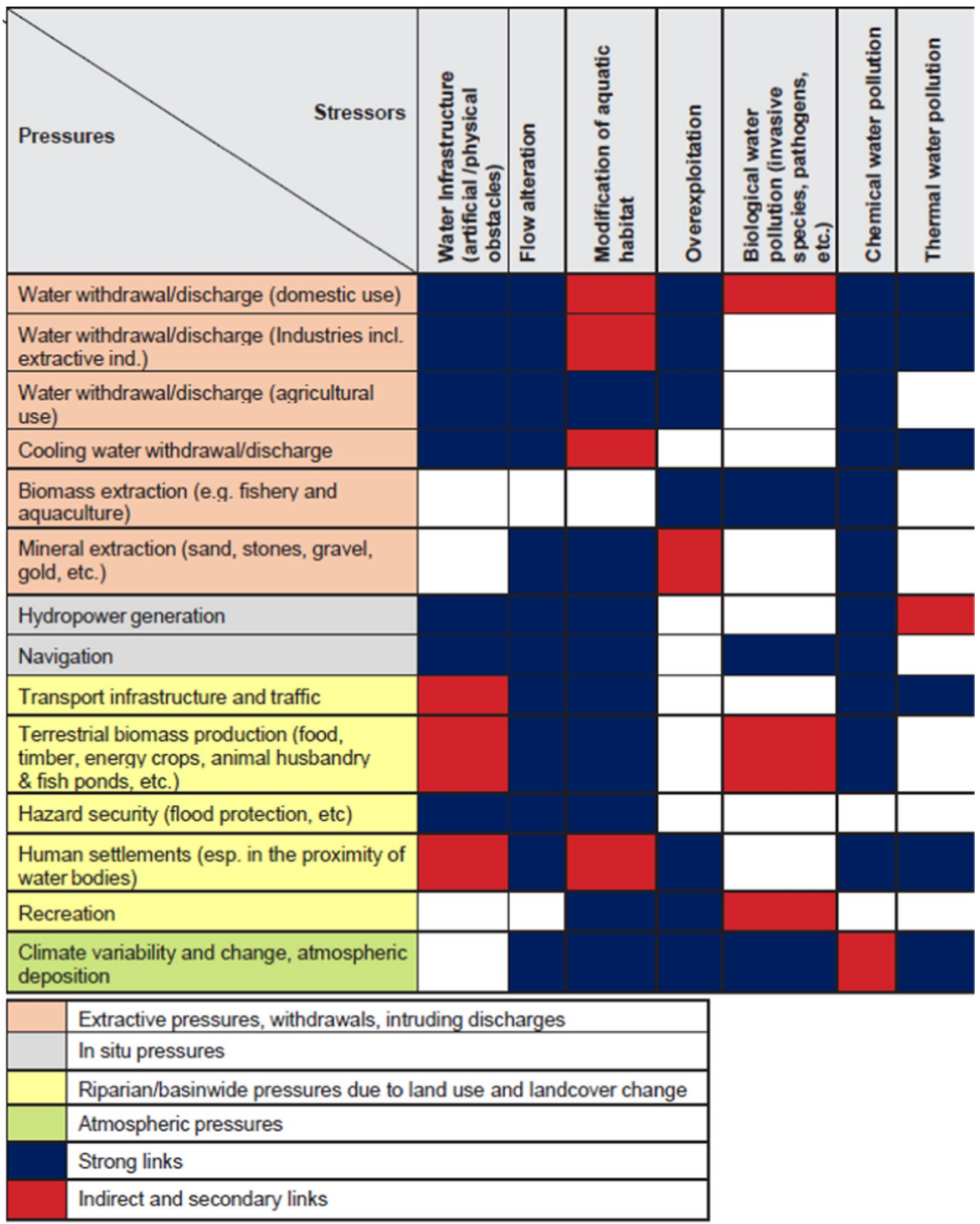

Pressures exert their influence on water bodies through hydraulic structures and river training, withdrawals, discharges, seepage through ground water bodies, atmospheric deposition, rainfall and radiation

et al. 2012; Smith et al. 2014). Water infrastructures can negatively influence both upstream and downstream water uses as well.

The construction of dams has already profoundly altered the character and condition of rivers and other wetland ecosystems. By the end of the twentieth century, over 58,000 large dams (dam height: $>15 \mathrm{~m}$ ) had been constructed globally across more than 140 countries (WCD 2000).

Although dams were mainly built in the developed countries in previous decades, the trend to plan and build dams and hydropower facilities has clearly shifted (Zarfl et al. 2015 and Grill et al. 2019). Given the growth in human 
population, economic development and the rapid rise in energy demand, this stressor is most likely gaining in importance. Indeed, within the next 10-20 years, hydroelectricity production will almost double, thus shaping the global river network considerably.

Many of the basins where such development is planned are also significant in terms of their conservation assets and ES values (Opperman et al. 2015).

\section{Flow alteration}

Hydrology is considered the "master variable" in inland waters (Poff et al. 1997; Jackson 2006). Flow alteration may be defined as "any anthropogenic disruption to the magnitude or timing of near-natural stream flows" (Rosenberg et al. 2000). Such changes in the magnitude and pattern of flows (or water levels), caused by the storage, regulation, diversion and/or extraction of surface and groundwater, are one of the primary contributors to the degradation in riverine ecosystems (Postel and Richter 2003). The physical (hard) and so-called soft (e.g. altered thermal regime) barriers created by water resources infrastructure fragment aquatic systems, blocking species movements between habitats and during migration, disconnecting rivers from their floodplains and associated wetlands and changing temperature, nutrient and sediment gradients and other processes (e.g. delta formation) needed for life cycle activities such as fish spawning. In addition to such effects due to water management, climate change and its adaptation responses, such as increased water storage, may also profoundly impact the hydrological, thermal, nutrient and sediment regimes of water bodies.

About $20-25 \%$ of continental run-off and about $25-30 \%$ of the total global sediment flux in rivers are now held behind reservoirs (Vörösmarty et al. 2003, 2004). Global fragmentation of rivers by such hydrological alteration is well documented. Nilsson et al. (2005) showed that 59\% of the world's large river systems (accounting for $60 \%$ of world run-off) were fragmented by flow regulation and channel fragmentation associated with dams, including the world's eight biogeographically most diverse systems. More recently, Lehner et al. (2011) report that $50 \%$ of the length of all rivers with discharge $>1000 \mathrm{~m}^{3} \mathrm{~s}^{-1}$ is impacted. They estimate that a combined storage capacity of approximately $8070 \mathrm{~km}^{3}$ may exist worldwide, increasing Earth's terrestrial surface water area by more than $305,000 \mathrm{~km}^{2}$. Some $65 \%$ of continental discharge is considered under moderate to high threat in terms of human water security and biodiversity (Vörösmarty et al. 2010).

By substantially changing the natural patterns of river flow and blocking the movements of fish and other biota, large dams, in particular, have severely disrupted the natural food production systems of rivers (e.g. fisheries, flood recession agriculture). This diminished food security has placed large downstream populations and their livelihoods at considerable risk (Richter et al. 2010).

More than half of all rivers globally are temporary, meaning that they fall dry at the surface for given periods of time; more permanent rivers are expected to turn temporary in the future due to climate change and overexploitation. The transformation of permanent to temporary waters fundamentally alters biodiversity and ecosystem processes. Flow intermittency per se is not necessarily a stressor in water courses having this phenomenon as a natural feature; however, human-caused alteration of flow regimes is frequently associated with other stressors such as water pollution and species invasion (Acuna et al. 2014).

Climate change-induced changes in precipitation will substantially alter important attributes of flow regimes in many rivers and wetlands and increase impacts from human water use in developed river basins (Döll and Bunn 2014). Around the world, changes to flow regimes resulting from shifts in precipitation and evaporation patterns have already been documented (Rosenzweig et al. 2008).

\section{Modification (degradation) of aquatic habitat}

Habitat degradation is a frequent stressor on all inland waters. For example, more than $50 \%$ of all wetlands have been lost worldwide (Finlayson and D'Cruz 2005). Largescale losses of habitat are expected to continue, particularly in the developing world, as inland water systems are further modified to provide electricity, water for irrigation, drinking water and sanitation services. Turning navigable rivers to waterways is done at the expense of natural flow conditions and massive changes in the morphology of the river bed.

Changes in land cover increase sedimentation, enrich nutrients, alter flow and lead to a decline of riparian areas (Allan 2004). In rivers, increased erosion following deforestation and other land use change can lead to inputs of sediment that decrease light penetration, clog the bottom habitat and disrupt the overall functioning of the ecosystem. In small Amazonian streams, clearing of tropical forest and conversion to pasture has been shown to change the biogeochemical and hydraulic characteristics of the system (Neill et al. 2006). At the extreme, whole mountaintops are removed for mining operations and the resulting dredge material is disposed of in nearby valleys, burying entire streams (Palmer et al. 2010).

Subtler degradation of aquatic environments is also commonplace. For instance, removal of wood debris from streams and lakeshores facilitates navigation and human recreation, but at the cost of simplifying the habitats. This can adversely affect populations of fish and other aquatic organisms. 


\section{Overexploitation}

Overexploitation refers to both overstressing water bodies in their function to provide ecosystem services, but also to excessive withdrawals and extraction of mineral resources. Overexploitation may affect ecological processes and biodiversity including evolutionary processes. Although it is difficult to determine the status of inland fisheries, there are strong indications that inland water bodies in most parts of the world are overexploited in this regard (Kura et al. 2004; Dugan et al. 2007).

\section{Biological water pollution}

Biological water pollution refers to invasive alien species and subspecies of plants and animals occurring outside of the range they occupy naturally or could not occupy without direct or indirect introduction or care by humans. Although the majority of alien species cause no immediate harm, some of them spread very rapidly as facing no natural enemies in the new environment. As competitors for food and habitat invasive species can harm biological diversity, human health economics and aesthetics.

Primary forms of biological pollution include deliberate introductions of species, aquaculture escapees, interbasin water transfers, ballast water from vessels, canals and releases from aquaria, gardens and bait buckets (Strayer 2010). Deliberate introductions occur for a variety of reasons-primary among these is the commercial or recreational harvest of the introduced species and biological control of other previously introduced species.

Species invasion may lead to faunal homogenization, alter ecosystem processes and, in some cases, cause the extinction of native species (Rahel 2000; Olden et al. 2008).

Beyond invasive species, the category of biological water pollution includes the occurrence of pathogens and parasites, threatening humans (Conn 2014) and aquatic species (Ashander et al. 2012; Meyer et al. 2015; Spikmans et al. 2013) and effects on the genetics of native species through escapees of captive bred stocks of, for example, fish (Baskett et al. 2013).

\section{Chemical water pollution}

Freshwater ecosystems suffer from the input of both nutrients and toxic chemicals due to human activities. Both nutrients and other types of chemical pollution stem from human waste and untreated human wastewater. Crop production involves the application of large amounts of nitrogen and phosphorus fertilizers in order to augment the yield. A portion of these nutrients run-off to rivers and lakes, where they can cause overgrowth of both plankton and aquatic plants. Emissions from cars, power plants and industry also contribute to nutrient loading. These emissions disperse in the atmosphere and long-distance atmospheric transport of nutrients has elevated inputs of nitrogen even in remote freshwaters that appear pristine. Near population centres, phosphorus from wastewater is a problem that requires societal investments in proper treatment technologies and control of inputs. Agriculture is responsible for excess non-point source pollutions.

Harmful chemicals are also a widespread threat to human and natural uses of freshwaters. Contaminants such as pesticides, fungicides, microplastic particles, heavy metals, pharmaceuticals and organics can reduce water quality to the point where rivers and lakes can no longer support a full complement of species and can even become unsuitable as source for high-quality water uses. For instance, acid rain arising from emissions of sulphur and nitrogen oxides was an acute problem in lakes and rivers of eastern North America and Europe until emissions controls became obligatory (Malmqvist and Rundle 2002). Highly acidic run-off continues to be problematic downstream of abandoned mine sites, making these streams uninhabitable for most species. A growing list of man-made chemicals used in industry and home products have been found in aquatic ecosystems, and scientists are still struggling to understand their prevalence and impact. Some of these disrupt the endocrine system of freshwater animals and people (Jobling et al. 1998; Mills and Chichester 2005); for instance, intersex fish possessing both male and female characteristics have been found in all nine of the large river basins sampled in the USA (Hinck et al. 2009).

Water quality is, moreover, expected to decline in some basins due to higher pollutant loads from heavy precipitation events, overflow of wastewater treatment plants during extreme rainfall and greater volume of withdrawal from lowquality sources (Kundzewicz et al. 2008).

In recent decades, net-cage aquaculture has become one of the main patterns of the intensive fish culture in lakes/ reservoirs in several countries (i.e. Indonesia, China, Ethiopia and the Philippines). Net-cage aquaculture is considered one of the major stressors on lake water quality. Organic and nutrient loading from excess feed and fish waste to lakes has resulted in organic accumulation in the sediment and lake water quality deterioration and accelerated the process of lake eutrophication and toxic cyanobacterial bloom (Guo and Li 2003; Hallare et al. 2009).

\section{Thermal water pollution}

Temperature influences the biology of every organism. Most aquatic organisms are adapted to a specific temperature range, outside of which temperatures become stressful and ultimately lethal. For example, the optimal temperature 
range for rainbow trout is between 13 and $15{ }^{\circ} \mathrm{C}$, with the lethal maximum of $24.3^{\circ} \mathrm{C}$ (Bear et al. 2007).

Thermal water pollution refers to an artificial increase or decrease in the temperature of a water body as a result of human activities (Kennedy 2004). Effects include lethal or sub-lethal effects of individual organisms and their development, adult migration, competition with non-native species (Riis et al. 2012) and the relative risk and severity of disease (Karvonen et al. 2010). Temperature also influences the capacity of water to hold dissolved oxygen (DO), which again affects aquatic organisms in various ways (Kennedy 2004). Specifically, in temperate lakes, thermal water pollution during winter was shown to be stored in the deep water column until the next winter. Accordingly, winter thermal water pollution can have a long-lasting negative effect on lake ecology (Kirillin et al. 2013).

Thermal water pollution (in the sense of the artificial temperature increase of recipient water bodies) is strongly associated with cooling water discharge, first and foremost from various types of power plants. Given the expected growth of energy demand on a global-scale, thermal pollution will increasingly become a concern. As the temperature of water bodies should not exceed certain thresholds to remain supportive for aquatic life, it is frequently the case that power plants need to shut down or curtail their power generation during summer periods as well as in the light of the climate change-driven increase in water temperature (van Vliet et al. 2012).

A less common form of thermal water pollution involves the release of cold water from reservoirs into warmer receiving water bodies. This occurs, for example, in Australia when cold water from reservoirs is released for irrigation purposes. If the water is released from the bottom of the reservoir, it can be considerably colder than the water in the receiving water body. The effects of cold-water pollution can be similar to that of warm-water pollution, but it has no negative impact on the water's DO holding capacity (Kennedy 2004).

Climate change-induced air temperature shifts are altering surface water temperatures in many temperate lakes, resulting in reduced periods of ice formation and the earlier onset and increased duration and stability of the thermocline during summer (Winder and Schindler 2004). These changes are projected to favour a shift in dominance to smaller phytoplankton and cyanobacteria (Settele et al. 2014). There is widespread evidence of rising temperatures (caused, at least partially by climate change) in streams and rivers over the past few decades, and this has been linked to shifts in invertebrate and fish community composition. These phenomena indicate how closely the different stressors are intertwined.

\section{Scientific and policy responses}

As a response to the above outlined stressors and their likely trends a sustained, global response is required to halt the ongoing losses of freshwater species and the degradation of freshwater ecosystem health. There is the risk of losing many services provided by aquatic ecosystems as well as the richness of biodiversity that they support. In response, society must devise strategies that leverage scientific understanding to reduce threats in ways that both protect aquatic biodiversity and enhance human well-being (see, e.g. Engloner et al. 2019).

The actions needed to counter these threats are often quite obvious. For instance, requiring adequate flow below dams or the complete decommissioning (removal) of dams is relatively simple solution to the suite of problems arising from damming rivers. However, resource limitations and human needs limit the range of feasible approaches, making it imperative to prioritize actions. Science-based, systematic methods for conservation and restoration planning applied to freshwater ecosystems at national and regional levels have advanced greatly in recent years (Nel et al. 2009). However, further work is needed, particularly to guide prioritization at continental and global levels. Large-scale datasets on species, ecosystems, drivers and threats (i.e. Freshwater Ecoregions of the World, ${ }^{6}$ DIVERSITAS, ${ }^{7}$ BioFresh,${ }^{8}$ GEOBON ${ }^{9}$ and the IUCN Red List of Threatened Species ${ }^{10}$ ) are already helping to make this goal achievable.

In responding to threats, narrowly focusing on what has changed in the last few 100 years and simply trying to reverse these changes is unlikely to be productive or possible. This is particularly pertinent in planning responses to climate change because it has the potential to completely change the context within which near-natural systems currently operate in the coming decades. Responding effectively to climate change in the context of freshwater ecosystem health requires reconceptualizing of what we perceive as natural systems and the actions that must be taken to conserve or rehabilitate them. For example, species' ranges may shift due to a changing climate. Through this adaptation process, competition between species may intensify as native species adjusting to a changing planet. New approaches to "climate-aware" water management are required in many basins across the globe as are governance structures with sufficient capacity and authority to deliver

\footnotetext{
${ }^{6}$ http://www.worldwildlife.org/pages/freshwater-ecoregions-of-theworld--2.

${ }^{7}$ http://www.diversitas-international.org/.

${ }^{8}$ http://project.freshwaterbiodiversity.eu/.

${ }^{9}$ http://geobon.org/.

$10 \mathrm{http} / / / \mathrm{www}$.iucnredlist.org/.
} 
that management (Matthews et al. 2009). Flexibility and adaptability, also in human endeavours, will be needed, as water managers will have to deal with ever greater climatic and eco-hydrological uncertainty (Milly et al. 2008; Matthews and Wickel 2009).

The stressors shown in Table 1 refer directly to the respective water body (freshwater ecosystem or part thereof), affecting it as point or non-point source influence. Stressors thus translate pressure(s) into specific and potentially negative consequences in or on water bodies. These can be characterized by

1. measuring the magnitude, spatial location, extent and duration of stressors,

2. describing the state of the respective water body which was exposed to the stressor(s) and

3. quantifying the impact of the stressor through the change of state (if the status prior to the stresses were known), as a consequence of the stressor(s).

Stressors, state(s) and impacts can be measured (and monitored) by means of direct and indirect indicators. Indicators can be associated with a single or several stressors. They measure either the attributes of a stressor directly (e.g. phosphorus or nitrogen load) or characterize the state of the water body (e.g. its trophic state). Thus, indicators are either stressor or state related. In general, indicators can be grouped into three main categories, namely

- hydromorphological indicators,

- physico-chemical indicators and

- biological indicators,

with further subdivisions.

The selection of indicators and the respective monitoring techniques employed depend largely on the water body type (although resource constraints also come into play). Three main water body types: lentic (lakes, reservoirs), lotic (rivers and streams) and palustrine wetland ecosystems, have been distinguished. Flowing waters are further subdivided into permanent and temporary and into wadeable and non-wadeable streams and rivers. The proposed stressors of freshwater ecosystems can primarily be characterized and monitored by a number of direct indicators, as listed in Table 2 . In case indirect indicators are applied, biological indicators are preferred because they reflect the alteration of freshwater habitats and biodiversity due to the aggregate effect of potentially several stressors.

Hydromorphological indicators are essential to characterize the physical environment, whether it is supportive of aquatic life. There are two major drawbacks to generalize this sort of indicators. They depend on whether the upper, middle or lower reach of watercourses (or transitional zones)
Table 2 Stressors of freshwater ecosystems and the respective types of direct indicators affected

\begin{tabular}{llll}
\hline Stressors & \multicolumn{2}{l}{ Indicators } & \\
\cline { 2 - 4 } & $\begin{array}{l}\text { Physico- } \\
\text { chemical }\end{array}$ & Biological & $\begin{array}{l}\text { Hydro- } \\
\text { morpho- } \\
\text { logical }\end{array}$ \\
\hline Water infrastructure & $\mathrm{X}$ & $\mathrm{X}$ & $\mathrm{X}$ \\
Flow alteration & $\mathrm{X}$ & $\mathrm{X}$ & $\mathrm{X}$ \\
Modification of aquatic habitat & & $\mathrm{X}$ & $\mathrm{X}$ \\
Overexploitation & & $\mathrm{X}$ & $\mathrm{X}$ \\
Biological water pollution & & $\mathrm{X}$ & \\
$\quad$ (invasive species) & & & \\
Chemical water pollution & $\mathrm{X}$ & $\mathrm{X}$ & \\
Thermal water pollution & $\mathrm{X}$ & $\mathrm{X}$ & \\
\hline
\end{tabular}

is concerned. Furthermore, the size of the water course matters as well.

An interesting linkage of the groups of biological, physico-chemical and hydromorphological indicators with the classification of different statuses of the respective water bodies is shown in Fig. 3. This classification, which is based on the EU Water Framework Directive (EC 2003), shows both a sort of hierarchical ordering of different kind of indicators and the role of the ultimate comparative decisions classifying the water bodies into one of the proposed ecological status categories.

Both Table 2 and Fig. 3 emphasize the primordial relevance of biological indicators for characterizing ecosystem health of freshwater bodies. Despite their importance, biological indicators unfortunately cannot be easily generalized. While the presence and reproduction of salmonids in cold freshwater bodies are a sign of their good status, this metric does not apply for example in tropical zones.

Figure 3 establishes a sort of hierarchy among the three categories of indicators. Given the above outlined difficulties with both biological and hydromorphological indicators, the physico-chemical indicators remain as the "least common denominator" type of indicator. After all, high level of dissolved oxygen or low nutrient concentrations can generally be used to characterize water quality, and (at least) implicitly freshwater ecosystem health.

\section{How to establish a general water quality guideline (WQG) for freshwater ecosystems}

A general WQG is to be developed to accommodate the broad context of climatic, biogeographic and hydromorphological conditions of individual freshwater ecosystems. These characterizations should be all-encompassing, yet not overly complex or unnecessarily detailed. It should be kept in mind that every standard, parameter and 


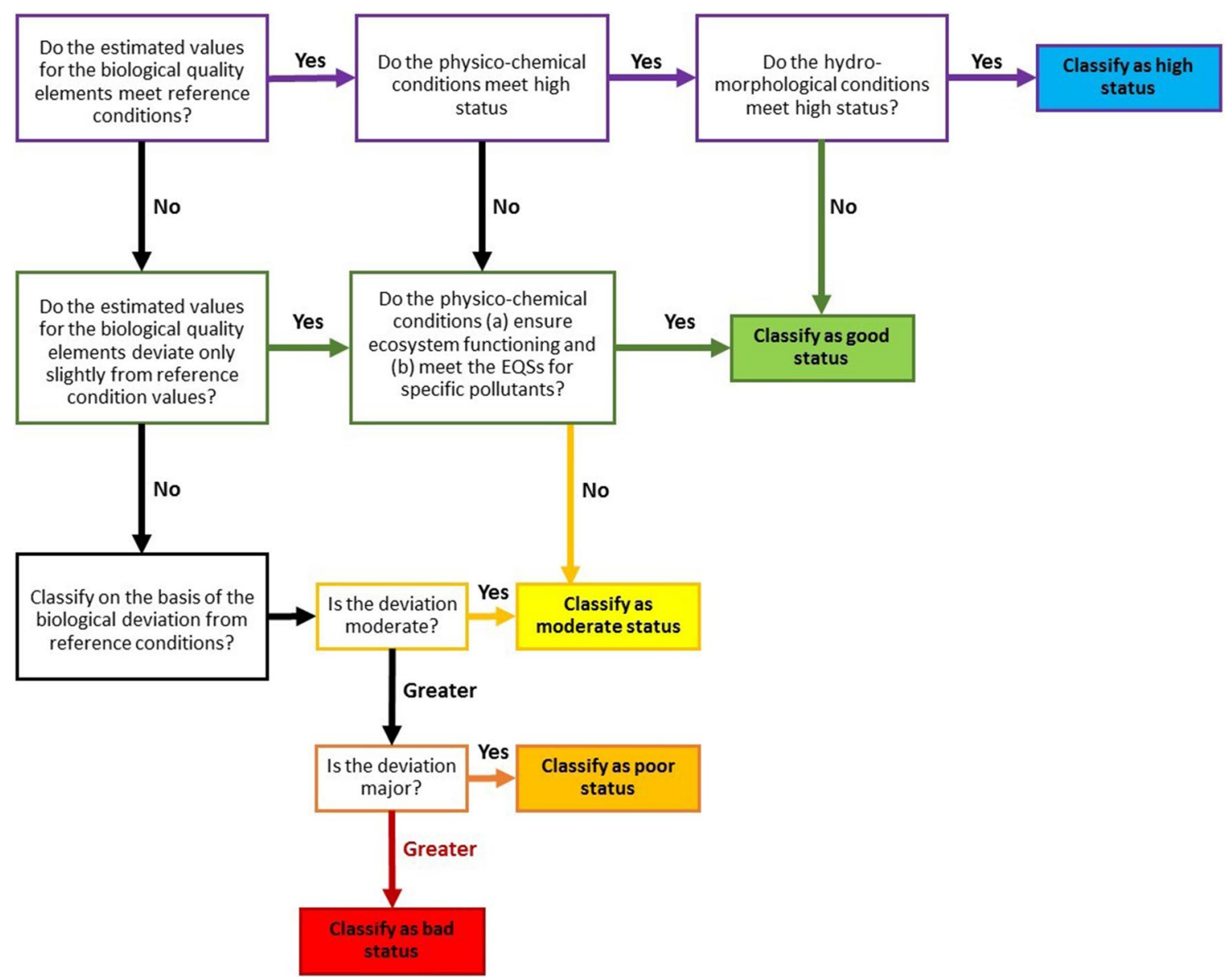

Fig. 3 Indication of the relative roles of the biological, hydromorphological and physico-chemical quality indicators in ecological status classification according to the normative definitions of the EU WFD. Source: EC (2003)

monitoring requirement may have serious and long-lasting costs and capacity implications. Professional and institutional engagement and their respective budgetary support are likely to be present in the decades-long cycles of adaptive water resources management. Therefore, a modular, stepwise option for identifying indicators and monitoring practices is envisaged, thereby enabling an adaptive implementation of assessment and remediation schemes. The proposed adaptive water quality assessment and management approach as shown in Fig. 4 is composed of four main phases:

1. Initiation phase Definition of the study area for which the guidelines will be used and setting of objectives covering Steps 1-3.

2. Identification phase Collecting and optimizing the use of existing data, knowledge and information covering Step 4.

3. Assessment Phase Collection of new data and assessment of prevailing conditions and trends, framework setting for classification, selection of indicators, monitoring and evaluation of the data including reporting covering Steps 5-7.

4. Policy Development Phase Integrating the guidelines into adaptive management and governance frames and setting priorities for further assessment and management of freshwater ecosystems covering Steps 8-9.

These four phases are subdivided into nine steps (in some cases with further subdivisions). In addition, the whole procedure is conceived as an adaptive management loop with a regular feedback, potential modification and subsequent re-run of Steps 1-9. Once the cycle is completed the original statement: "Need for Ecosystem Improvement" changes to a, from here onwards repeated question: "Is there still a Need for further Ecosystem Improvement?". In Step 5, the description "indicators of concern" stresses the importance to select the relevant indicators only for further monitoring. Thereby, the number of parameters to be observed could be reduced. Steps 6 and 7 have to be revisited in short-term (annual) cycles. The entire cycle (Steps 1-9) needs to be revisited in 5-10 years. 


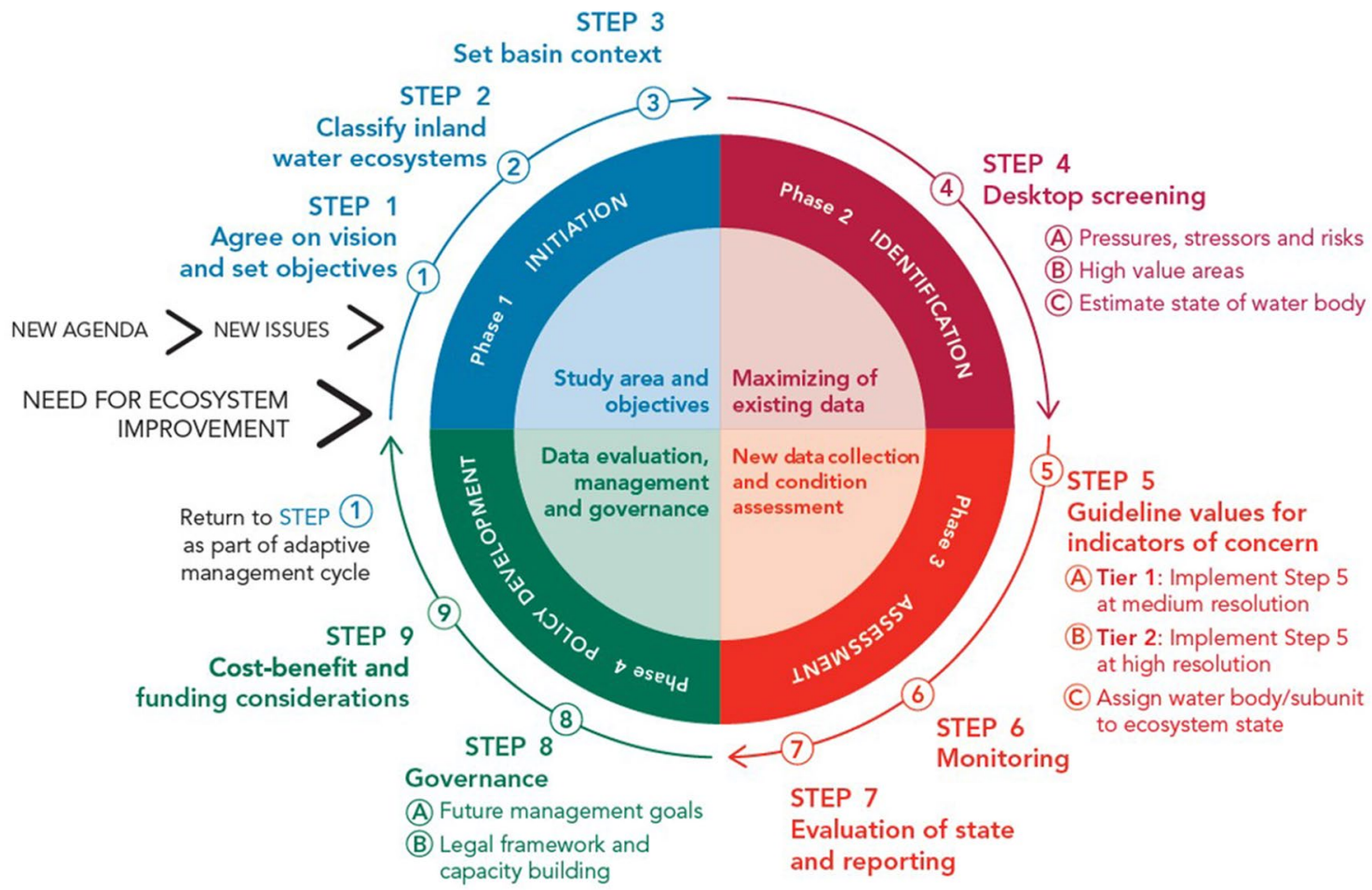

Fig. 4 Overview of the proposed adaptive approach with 4 phases and 9 steps

Beyond this recommended, approximately decadal review of the 4-phase 9-step smaller iterative cycles should be envisaged and implemented more frequently. For example, revising ecosystem health class assignments in Step 5c if evaluation and reporting of monitoring results in Step 7 should prove their infeasibility.

Moving from Tier 1 towards Tier 2 approaches (Steps 5A and 5B in Fig. 4), the diagnostic capability and confidence in the conclusions increase. The decrease of uncertainty, however, is associated with higher costs and more sophisticated technical requirements. There are obvious trade-offs among these factors.

It is worth to notice that the adaptive scheme as shown in Fig. 4 was adopted, modified and recommended by UN Environment in its FFEM (2018) for widespread use. Figure 5 shows this 4 -phase 12-step model. The biggest difference between the original and the modified adaptive approach is in phase 4 where, compared to Fig. 4 and Fig. 5 refers explicitly to steps of success control and the introduction of potential modifications.

\section{Benchmarks to characterize the health of freshwater ecosystems}

The fundamental scientific and policy task of water management programmes is to set thresholds to distinguish "good" (acceptable/desirable) from "bad" (unacceptable/ undesirable) conditions. In general, these thresholds demarcating acceptable from unacceptable chemical, physical and biological conditions are referred to as benchmarks. From an ecosystem perspective, it is important to set high integrity (i.e. natural or close to natural conditions) as an aspirational goal. This reflects a societal objective of maintaining biodiversity and protecting key ecological processes. There is hardly any disagreement that where possible the lowest benchmark for ecosystem protection should still correspond with a quality status that supports a balanced, integrated and adaptive community of organisms having a composition and diversity comparable to that of the natural habitats of a region (Frey 1975).

In some regions, it may be still possible to set upper targets relative to a certain "reference" condition (RC), a condition undisturbed by human activities that can serve as an anchor point for comparison, such as applied in the Australian River Assessment System (AUSRIVAS) (Schofield and Davies 1996) and the River Invertebrate Prediction and Classification System (RIVPACS) (Wright 1995). This of course assumes that there are places in the landscape that have been relatively free from intensive human activity or there is historical information available to reflect conditions prior to human influence. For some water quality indicators, such as pesticides or other novel compounds, it can be assumed that the reference value was "zero". Similarly, for biological indicators such as the 
Fig. 5 The 4-phase 12-step model of the framework of freshwater ecosystem management (UN Environment 2018)
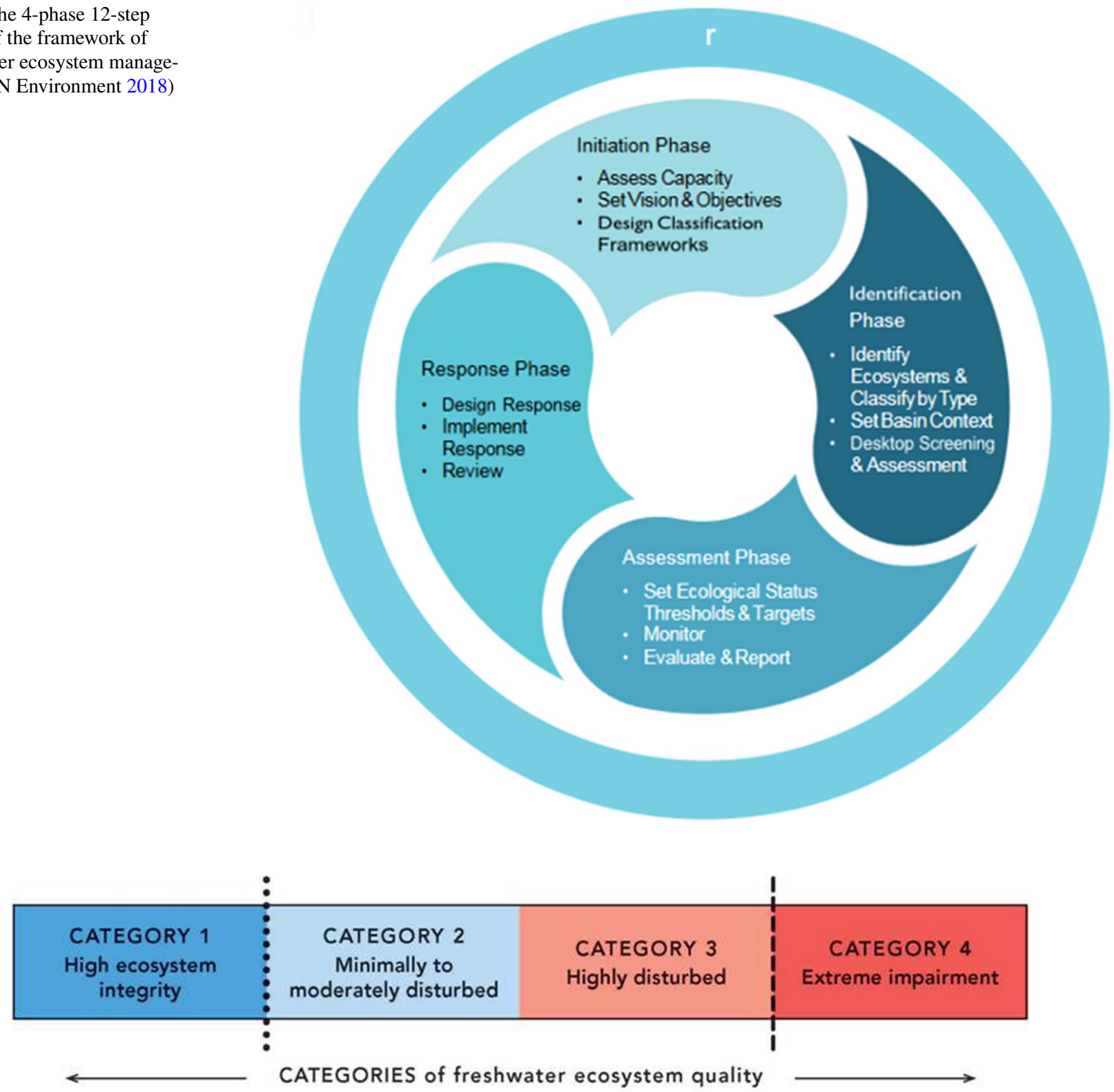

Fig. 6 Categories of freshwater ecosystem quality. The dotted and dashed bars indicate the two benchmarks discussed in the text

percentage of alien species, we can assume that a reference value was also "zero".

Such RCs do not necessarily have to constitute an attainable target condition, but they provide transparency about how far an ecosystem has departed from its natural state. This information helps setting realistic restoration targets in areas of widespread human disturbance. In contrast, setting a low target would concede that it is acceptable if ecosystem health is simply maintained above some minimum value and this would in consequence increase the risk of further biodiversity loss and diminished ES.

Figure 6 provides an example of how the range of acceptable and inacceptable conditions for a given ecosystem might be characterized. Setting benchmarks for high ecosystem integrity (Category 1) and for extreme impairment (Category 4) provide important "anchor points" for condition indicators. In this scheme, RC (if known) would be "extreme left" at the upper limit of Category 1. The lowest benchmark would be the upper threshold of Category 4. Above this level, the ecosystem, which is in a "highly disturbed" state may still support some higher multi-cellular life forms. In the case of water quality parameters, the benchmarks demarcating Category 4 would be values known to be acutely toxic to algae, invertebrates and/or fish. For biological indicators, such as species richness or diversity, these would be values near zero. 


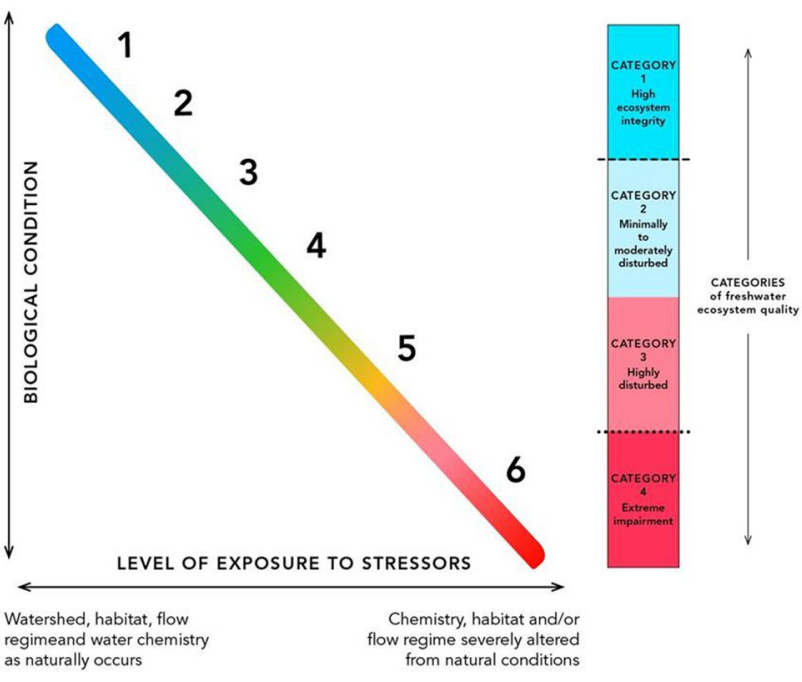

Fig. 7 The biological condition gradient and the proposed ecosystem health categories. Source: Modified from Davies and Jackson (2006) and US EPA (2011)

However, thresholds of concern between these two extremes that would trigger management actions if reached (illustrated between the dashed and dotted vertical lines in Fig. 6) need to be established. These benchmark levels are also sometimes called "thresholds of concern" in the respective scientific literature. They may serve also to separate subcategories and indicate success or failure (or lack) of rehabilitation efforts.

Setting appropriate upper target values is not always straightforward given the often irreversible damages that have been inflicted upon the landscape. Accommodations must be made to account for these changes while providing for setting best attainable ecological conditions in current circumstances and best practices for remediation and management.

By comparing the proposed four categories with the wellknown classification scheme, the biological condition gradient (BCG) (US EPA 2011) is shown in Fig. 7 similarities and also emphasizes the factor exposure to stressors.

\section{Proposed physico-chemical benchmarks to characterize high ecosystem integrity and extreme impairment, respectively}

Table 3 provides freshwater benchmark values for physical and chemical indictors which are indicative of high ecosystem integrity and extreme impairment, respectively. Biological benchmarks, as indicated earlier, are essential to final assessment of freshwater ecosystem health status. However, they cannot be advised on the basis of different guidelines developed under diverging climatic and hydrological regimes. Even physico-chemical benchmarks may vary considerably due to different natural conditions which heavily influence dissolved oxygen levels, temperature or even $\mathrm{pH}$ value of the water. The criteria and standards in the following countries and regional agencies are considered for comparison: Australia/New Zealand, Canada, China, EU, Japan, South Africa, United Nations Economic Commission for Europe (UNECE) and the USA.

The first benchmark value will separate ecosystems of high integrity (Category 1) from other ones. The second benchmark demarcates the lower end of the quality continuum where water quality severely constrains the existence of most forms of multi-cellular life and ecological structure and function (Category 4). Values to demarcate the difference between minimally to moderately disturbed ecosystem states (Category 2) and highly disturbed ecosystems (Category 3) represent intermediate thresholds that should be subject to more specific considerations because of locally relevant physical, chemical and hydromorphological conditions and management objectives.

The proposed benchmark values for the selected physicochemical indicators are summarized in Table 3 . These values are based on internationally and nationally established criteria and standards to protect highly intact freshwater ecosystems and to characterize severe ecosystem degradation, respectively. As in the EU WFD only environmental quality standards (EQS) for priority pollutants are established, the numerical values of the UK standards are used for comparison of other indicators. The proposed benchmarks are close to the median values of the criteria and standards in the guidelines considered. See the Supplementary Material for background information and an overview of criteria and standards which are considered for arriving at the proposed IWQGES benchmark values. Further details are available in Annex 3 of Volume 4 of FFEM (UN Environment 2018).

Ever since the compilation of the report IWQGES in 2016 and the publication of FFEM (UN Environment 2018), the importance of water quality guidelines for freshwater ecosystems became more and more relevant. In this part of the paper, recent publications will be analysed to trace whether and how far the above-mentioned background documents contributed to emerging scientific assessments of freshwater ecosystem health. As SDG 6, the dedicated water goal (UNGA 2015) contains explicit targets for improved water quality and biodiversity preservation and rehabilitation; it was expected that this intergovernmental mandate will inevitably trigger research on assessment of the status quo and on indicators which may enable measuring progress towards the achievement of the goals and respective targets.

Another benchmark event in 2015 with relevance to the health of freshwater ecosystems was the UNFCCC Conference of the Parties (COP21) held in Paris. The outcome document, the Paris (Climate) Agreement stipulated that the 
Table 3 Proposed IWQGES physico-chemical benchmarks for freshwater ecosystems

\begin{tabular}{|c|c|c|}
\hline & High integrity (category 1$)^{\mathrm{a}}$ & Extreme impairment (category 4) \\
\hline Dissolved oxygen saturation (\%) & $80-120$ & $<30$ or $>150$ \\
\hline Dissolved oxygen concentration (mg/l) & $7.3-10.9^{b}$ & $<3$ or $>13.6^{\mathrm{b}, \mathrm{c}}$ \\
\hline (Optional) $\mathrm{BOD}_{5}(\mathrm{mg} / \mathrm{l})$ & $<3$ & $>10$ \\
\hline \multicolumn{3}{|l|}{ Total phosphorus $(\mathrm{TP})(\mu \mathrm{g} / \mathrm{l})$} \\
\hline Lakes and reservoirs & $<10$ & $>125$ \\
\hline Rivers and streams & $<20$ & $>190$ \\
\hline \multicolumn{3}{|l|}{ Total nitrogen $(\mathrm{TN})(\mu \mathrm{g} / \mathrm{l})$} \\
\hline Lakes and reservoirs & $<500$ & $>2500$ \\
\hline Rivers and streams & $<700$ & $>2500$ \\
\hline \multicolumn{3}{|l|}{ Chlorophyll $a(\mu \mathrm{g} / \mathrm{l})$} \\
\hline Lakes and reservoirs & $<3.0$ & $>165$ \\
\hline Rivers and streams & $<5.0$ & $>125$ \\
\hline $\mathrm{pH}$ & $6.5-9.0$ & $<5$ or $>9$ \\
\hline Temperature & $\begin{array}{l}\text { No deviation from background value or reference } \\
\text { systems or optimum temperature ranges of relevant } \\
\text { species }\end{array}$ & $\begin{array}{l}\text { Large deviations from background value or } \\
\text { the thermal tolerance range for characteris- } \\
\text { tic species }\end{array}$ \\
\hline Un-ionized ammonia $\left(\mu \mathrm{g} \mathrm{NH}_{3} / \mathrm{l}\right)$ & $15^{\mathrm{e}}$ & $100^{\mathrm{e}}$ \\
\hline \multicolumn{3}{|l|}{ Aluminium $(\mu \mathrm{g} / \mathrm{l})$} \\
\hline $\mathrm{pH}<6.5$ & 5 & - \\
\hline $\mathrm{pH}>6.5$ & 10 & 100 \\
\hline Arsenic $(\mu \mathrm{g} / \mathrm{l})$ & 10 & 150 \\
\hline Cadmium $(\mu \mathrm{g} / \mathrm{l})^{\mathrm{d}}$ & 0.08 & 1.0 \\
\hline \multicolumn{3}{|l|}{ Chromium $(\mu \mathrm{g} / \mathrm{l})^{\mathrm{d}}$} \\
\hline $\mathrm{Cr}$ III & 10 & 75 \\
\hline Cr VI & 1 & 40 \\
\hline Copper $(\mu \mathrm{g} / \mathrm{l})^{\mathrm{d}}$ & 1 & 2.5 \\
\hline Lead $(\mu \mathrm{g} / \mathrm{l})^{\mathrm{d}}$ & 2 & 5 \\
\hline Mercury $(\mu \mathrm{g} / 1)^{\mathrm{d}}$ & 0.05 & 1.0 \\
\hline $\operatorname{Nickel}(\mu \mathrm{g} / \mathrm{l})^{\mathrm{d}}$ & 20 & 50 \\
\hline $\operatorname{Zinc}(\mu \mathrm{g} / 1)^{\mathrm{d}}$ & 8 & 50 \\
\hline
\end{tabular}

Annual average total concentrations, unless indicated otherwise

${ }^{a}$ Natural sources and geographical conditions may cause natural background values that differ from the benchmarks for high integrity. Instead of these benchmark values, natural background concentrations may be used for setting criteria for high integrity

${ }^{\mathrm{b}}$ Dissolved oxygen concentration varies depending on temperature, pressure and salinity; benchmarks are for freshwater at sea level (760 mm $\mathrm{Hg}$ ) and $20^{\circ} \mathrm{C}$ based on the DO \%

${ }^{c}$ Daily average

${ }^{\mathrm{d}}$ Applicable for waters with low hardness $\left(<60 \mathrm{mg} / \mathrm{CaCO}_{3}\right)$. In case of higher hardness, the benchmark values may be somewhat higher ${ }^{\mathrm{e}}$ Corresponding total ammonia $\left(\mathrm{NH}_{3}+\mathrm{NH}^{+}\right)$concentration depends on $\mathrm{pH}$ and temperature. At $\mathrm{pH} 7.5$ and $20{ }^{\circ} \mathrm{C}$, the benchmarks for total ammonia- $\mathrm{N}$ are $1000 \mu \mathrm{g} / \mathrm{l}$ and $6641 \mu \mathrm{g} / \mathrm{l}$, respectively

atmospheric temperature increase over the average which prevailed before the industrial revolution should be limited to $2^{\circ}$ (but preferably should remain below $1.5^{\circ}$ ). This requirement implies drastic reduction and ultimately $\mathrm{CO}_{2}$ neutral energy generation.

In order to satisfy the increasing (clean) energy demand of the world (which would be needed to reach other SDG goals), the massive development of all kind of renewable energy sources is inevitable. Zarfl et al. (2015) reported increased dam building worldwide. Due to the inherent fragmentation of streams, this development does not augur well for freshwater ecosystem health. This concern was echoed during the Science panel session of the recent 3rd Budapest Water Forum held in October 2019. It was cautioned that freshwater biodiversity could be the first victim of the Paris Agreement of 2015 (Tockner 2019). Therefore, other renewables such as solar, wind and biogas must be urgently considered and supported.

Even the water-energy-food security nexus, which was championed by the respective Bonn Conference in 2011 
and focuses on the interlinkages, synergies and trade-offs between the various sectors and their respective increasing aspirations implies threats for freshwater ecosystems worldwide. In a recent paper, Shumilova et al. (2018) investigated the status of existing, being built and planned water transfer schemes. This study focused exclusively on so-called water transfer megaprojects (WTMPs), i.e. those projects, which fulfil at least one of the following criteria: (1) having construction costs of at least 1 billion US\$, (2) having a water transfer length of over $190 \mathrm{~km}$ or/and (3) an annual transfer volume of at least 230 million $\mathrm{m}^{3}$. The study identified 76 projects in the category of WTMPs.

The results of this assessment show a staggering threat potential on its way towards realization. Should all of these projects become reality they would convey water over an aggregated distance of more than $80,000 \mathrm{~km}$ (twice the length of the equator), would cost a staggering 2663 billion US\$ and transfer across watersheds almost $2000 \mathrm{~km}^{3}$ water annually. This amount is about $50 \%$ of the proposed planetary boundary for the annual freshwater use by humans (Rockström et al. 2009).

Inter-basin transfers are probably the most effective (and consequently most dangerous) means to spread invasive species into hitherto unaffected streams and lakes. By considering that WTMPs are only the tip of the iceberg, the potential threat for freshwater ecosystem health cannot be neglected. It has to be added that the inherent trade-offs may influence the achievement of competing SDGs and their respective targets.

The concept of water stressors, which is introduced also in this paper, is one of the core ideas of IWQGES and FFEM. It is implicitly and explicitly considered in recent scientific assessments of freshwater ecosystem health. The mapping of the world's free flowing rivers (Grill et al. 2019) is an outstanding example to prove this point. Based on an integrated Connectivity Status Index (CSI) which considers longitudinal (between upstream and downstream), lateral (between river channel and floodplains), vertical (between surface and groundwater bodies and connectivity with the atmosphere) and temporal (based on the seasonality of flow) connectivity (Ward 1989), different categories of rivers: short (10-100 km long), medium (length between 100 and $500 \mathrm{~km}$ ), long (500-1000 km) and very long streams (over $1000 \mathrm{~km}$ long), were assessed.

Rivers having along their entire length a CSI value at, or above $95 \%$ were considered free flowing, though a CSI value below $100 \%$ shows already diminished connectivity. About $50 \%$ of all river reaches worldwide have CSI values between 95 and $100 \%$. Almost $10 \%$ of all analysed river reaches (1.1 million $\mathrm{km}$ of aggregated length) had CSI values below 95\%, thus indicating significant reduction of connectivity. The analysis showed that the percentage of long and very long rivers (above 500 and $1.000 \mathrm{~km}$ length, respectively) have the largest percentage of non-free flowing reaches. While two-thirds of the very long rivers are classified as non-free flowing, this percentage is even higher (77\%) for those very long rivers which are connected directly to the ocean.

Rivers draining "cultural landscapes" and having industrialized or/and overpopulated basins, or having been developed for large-scale hydropower generation and ship locks for navigation are among those which show the biggest deteriorations in terms of CSI values which remain inferior to 95\% along the entire length of the respective watercourse.

The characterization of the ecosystem health status of water bodies, here rivers and water courses, with the help of measuring the extent of different stressors directly is an interesting approach. No doubt, for example, that the increasing degree of fragmentation is detrimental to any water course, irrespective whether it is an arctic river or located in the tropics and whether discharging into an ocean or drains an endorheic basin. Thus, using indicators related directly to stressor levels circumvents the constraints of both biological and hydromorphological indicators. No doubt, however, that the scientific consensus about the effects of the respective stressor is a prerequisite for a successful use of stressor-related (proxy) indicators.

Grill et al. (2019) highlight the importance and ranking of stressors for freshwater bodies. (Note that the terminology "pressure indicator" used in the referred paper corresponds with what is called stressor and their potential indicators in this paper.)

It is important to note that over two-thirds of the cases the degree of fragmentation (DOF) dominates the stress the water body is exposed to, followed by the degree of regulation. These two stressors account for over $90 \%$ of the deterioration of the CSI value below the proposed threshold of $95 \%$. These results emphasize the overwhelmingly detrimental effects of dams, barrages and weirs and the likes as prime stressors of the health of freshwater bodies and their biodiversity.

The robustness of this result makes it unlikely that by using different indicators than the CSI the results would significantly change. While decommissioning of dams is possible, it is by far not a frequent but an increasing remedial action to improve ecosystem health of water bodies.

It is obvious that different scales and purposes of freshwater ecosystem health assessments need different indicators. The global comparison and classification of rivers into free flowing or impacted categories is a different exercise than assessing the status of a small or medium size river or lake. Even along a watercourse the characteristics which define ecosystem quality can significantly vary. We also argue that biological indicators are the most adequate ones to capture and characterize freshwater ecosystem health. However, it is very difficult to establish biological criteria and indicators and their respective threshold values which might have 
global (or at least regional) validity, similar to consensus thresholds for physico-chemical or morphological indicators. As the summary of the source material reveals (see Supplementary Material) the proposed threshold values showed a considerable spread and variability. Morphological and/or built infrastructure (stressor)-oriented indicators, like the CSI of Grill et al. (2019), can be seen as adequate proxies at regional and global scale.

Increasing pressures and stresses on water bodies worldwide, e.g. through the development of hydropower plants, generate conflicts among SDG targets. To monitor the impacts, highlight critical developments and to identify appropriate interventions, water quality guidelines for ecosystems are a great asset as they consider an entire set of drivers, pressures, stressors and impacts alongside with an adaptive response cycle. Water quality monitoring does take place in a strong societal context. Its success depends on many factors as analysed by Kirschke et al. (2020). Progress has been made in the assessment of stressors such as infrastructure and flow modification and their strong consequence, river fragmentation. Fragmentation of river bodies might or might not be seen as an acceptable price for clean energy and water diversion schemes for drinking water, irrigation, flood control and transport. The long-term consequences are yet to be seen and discussed within societies. Reduction of the impacts is key to preserve or improve aquatic ecosystem health.

\section{Conclusions for future biology and for future water resources management}

The sustainable use and the protection of water resources and water bodies necessitate the consideration of rivers, lakes, wetlands and groundwater bodies as ecosystems with their particular water quality and quantity characteristics and requirements. This is needed both for the provision of ecosystem services to society and for a non-utilitarian approach, whereby freshwater ecosystems, their biodiversity and stability are to be addressed for their own sake, without automatically assessing its utility for societal purposes.

Consequently, guidelines, preferably with global validity, would be needed to monitor and assess the status of freshwater bodies and accordingly consider also non-utilitarian goals. These guidelines with their benchmarks considering and characterizing the requirements for the conservation of ecosystem integrity could, once well developed and tested, enable to fine-tune more sustainable societal appropriation of water as a resource and other ecosystem services provided by freshwater bodies, without threatening their stable functioning as habitat.

The UN Environment commissioned scientific study (IWQGES), and based on it, the Framework for Freshwater
Ecosystem Management (FFEM 2018) identified seven water stressors to account for different categories and levels of threat faced by water bodies through excessive anthropogenic influences. This paper also outlined the approach to conceive, develop and iteratively adapt the kind of water quality guideline needed as basis of a freshwater ecosystem health oriented water resources management. The cited studies and subsequent scientific papers show that indicators with potentially universal applicability are still rather quantify different stress levels than directly describe the (impacted) biological status. Hence, further research is needed towards the operationalization of indicators assessing the different components of freshwater ecosystem health.

Given the strong influence of climatic, hydrological, geological, geochemical and other geographical factors, which co-determine their biological composition, healthy freshwater ecosystems in different parts of the world may differ from each other considerably. Hence, simple classification on the basis of consensus biological indicators and respective threshold values does not seem yet as a viable approach. In a different context, the same applies also for hydromorphological indicators. The natural features of a stream, for example, vary considerable along its course from the source to the mouth.

However, there is increasing awareness for the necessity to give freshwater ecosystems the status of a "water user". The paper outlines along these lines both scientific and management concepts. The present limitations to characterize the state of health of freshwater bodies should rather serve as incentives for research than be seen as a permanent drawback. Given the global trend of deteriorating freshwater ecosystem health, further development along the lines outlined in this paper is a must.

Acknowledgements Open Access funding provided by Projekt DEAL The report of the International Water Quality Guideline (IWQGES) project was compiled, next to the authors of this paper, by members of the UNU-EHS project team: Fabrice Renaud, Nike Sommerwerk, Yvonne Walz, and members of the scientific Drafting Committee: Stuart Bunn, Joseph Flotemersch, Cynthia Henny, Kenneth Irvine, Claudia Pahl-Wostl, László Somlyódy, Paul Stortelder, Rebecca Tharme and Klement Tockner. We are pleased to acknowledge the substantial contributions of the Advisory Group (AG), of which: the members were nominated by Member States of the United Nations Environmental Assembly and invited by UN Environment to critically review, advise and contribute to the subsequent draft versions of IWQGES; the members of the AG, representing their countries were Mehmed Cero (Bosnia and Herzegovina), Monica Porto (Brazil), Chazhong Ge (China), Nassere Kaba (Côte d'Ivoire), Harry Liiv (Estonia), Marta Moren Abat (European Commission), Fritz Holzwarth (Germany), Sabah Obaid Hamad Al Shujairi (Iraq), Deborah Chapman (Ireland), In Ae Huh (Republic of Korea), Mohamed Salem Hamouda (Libya), Ahir Malik (Pakistan), Elena Dumitru (Romania), Jarmila Makovinská (Slovakia), Yakup Karaaslan (Turkey), Simon Etimu (Uganda), Nadhifa Kemikimba (United Republic of Tanzania), Sasha Koo-Oshima (USA), Nyaradzayi Anna Mawango (Zimbabwe). Furthermore, helpful discussions took place and comments were received for various IWQGES 
drafts from Maija Bertule, Paul Glennie, Peter Koefoed Bjørnsen and Marcelo Pires da Costa. These valuable contributions are gratefully acknowledged. The contributions of Paul Glennie were instrumental in the preparation of the Framework for Freshwater Ecosystem Management (FFEM). The following staff members of UN Environment provided dedicated support and guidance but also comments and contributions to the reports: Keith Alverson, Aruwa Bendsen, Thomas Chiramba, Joakim Harlin, Birguy Lamizana, Elisabeth Mullin- Bernhardt, Emmanuel Ngore and Yeonju Jeong. (Names within each group and countries are in alphabetical order.)

Funding The report IWQGES (2016), which served as basis for the UN Environment Framework for Freshwater Ecosystem Management publication (2018), was funded by UNEP. The present paper was prepared without financial support.

Data availability No new primary data were used in this paper. Sources of information like websites of agencies publishing data or guidelines are referred to.

\section{Compliance with ethical standards}

Conflict of interest The authors declare that they have no conflict of interest.

Ethical approval In the research which led to this paper, no experiments including living organisms were carried out.

Open Access This article is licensed under a Creative Commons Attribution 4.0 International License, which permits use, sharing, adaptation, distribution and reproduction in any medium or format, as long as you give appropriate credit to the original author(s) and the source, provide a link to the Creative Commons licence, and indicate if changes were made. The images or other third party material in this article are included in the article's Creative Commons licence, unless indicated otherwise in a credit line to the material. If material is not included in the article's Creative Commons licence and your intended use is not permitted by statutory regulation or exceeds the permitted use, you will need to obtain permission directly from the copyright holder. To view a copy of this licence, visit http://creativecommons.org/licenses/by/4.0/.

\section{References}

Acuna V, Datry T, Marshall J, Barcelo D, Dahm CN, Ginebreda A, McGregor G, Sabater S, Tockner K, Palmer MA (2014) Why should we care about temporary waterways? Science 343:1080 1082. https://doi.org/10.1126/science.1246666

Allan JD (2004) Landscapes and riverscapes: the influence of land use on stream ecosystems. Annu Rev Ecol Evol Syst 35:257-284

Allan JD, Flecker AS (1993) Biodiversity conservation in running waters. Bioscience 43:32-43

Allen DJ, Darwall WRT, Smith KG (2012) The status and distribution of freshwater biodiversity in Indo-Burma. International Union for Conservation of Nature, Cambridge

Ashander J, Krkosek M, Lewis M (2012) Aquaculture-induced changes to dynamics of a migratory host and specialist parasite: a case study of pink salmon and sea lice. Theor Ecol 5:231-252

Ayers RS, Westcot DW (1985) Water quality for agriculture. Food and Agriculture Organization of the United Nations, Rome
Barbour MT, Gerritsen J, Snyder BD, Stribling JB (1999) Rapid bioassessment protocols for use in streams and wadeable rivers. US Environmental Protection Agency, Washington, D.C.

Bartram J, Balance R (1996) Water quality monitoring. A practical guide to the design and implementation of freshwater quality studies and monitoring Programmes. Published on behalf of UNEP and WHO, E\&FN Spon, London, p 383

Baskett ML, Burgess SC, Waples RS (2013) Assessing strategies to minimize unintended fitness consequences of aquaculture on wild population. Evol Appl 6:1090-1108

Bear EA, McMahon TE, Zale AV (2007) Comparative thermal requirements of west slope cutthroat trout and rainbow trout: implications for species interactions and development of thermal protection standards. Trans Am Fish Soc 136:1113-1121

Brisbane Declaration (2007) The Brisbane declaration of the international river symposium and international environmental flows conference. Brisbane, Australia. http://www.eflownet.org/downl oad_documents/brisbane-declaration-english.pdf. Accessed 2 Feb 2016

Bunn SE, Davies PM, Mosisch TD (1999) Ecosystem measures of river health and their response to riparian and catchment degradation. Freshwater Biol 41:333-345

Butchart SHM, Walpole M, Collen B, von Strien A, Scharlemann JPW, Almond REA, Baillie JEM, Bomhard B, Brown C, Bruno J, Carpenter KE, Carr GM, Chanson J, Chenery AM, Csirke J, Davidson NC, Dentener F, Foster M, Galli A, Galloway JN, Genovesi P, Gregory RD, Hockings M, Kapos V, Lamarque J-F, Leverington F, Loh J, McGeoch MA, McRae L, Minasyan A, Hernández Morcillo M, Oldfield TEE, Pauly D, Quader S, Revenga C, Sauer JR, Skolnik B, Spear D, Stanwell-Smith D, Stuart SN, Symes A, Tierney M, Tyrrell TD, Vié J-C, Watson R (2010) Global biodiversity: indicators of recent declines. Science 328:1164-1168

Conn DB (2014) Aquatic invasive species and emerging infectious disease threats: a one health perspective. Aquat Invasions 9:383-390

Constantino C, Falcitelli F, Femia A, Tuolini A (2003) Human environment interaction. ISTAT OECD-workshop Paris, 14-16 May 2003

Corcora E, Nellemann C, Baker E, Bos R, Osborn D, Savelli H (eds) (2010) Sick water? The central role of wastewater management in sustainable development. A rapid response assessment. United Nations Environment Programme, UN-HABITAT, GRID-Arendal. http://www.grida.no/publications/rr/sickwater/. Accessed 2 Feb 2016

Davies SP, Jackson SK (2006) The biological condition gradient: a conceptual model for interpreting detrimental change in aquatic ecosystems. Ecol Appl 16:1251-1266

DeZuane J (1997) Handbook of drinking water quality. Wiley, New York

Döll P, Bunn SE (2014) Impact of climate change on freshwater ecosystems due to altered river flow regimes. In: Field CB, Barros VR, Dokken DH, Mach KJ, Mastrandrea MD, Billir TE, Chatterjee M, Ebi KL, Estrada YO, Genova RC, Girma B, Kissel ES, Levy AN, MacCracken S, Mastrandrea PR, White LL (eds) Climate change 2014: impacts, adaptation and vulnerability. Part A: global and sectoral aspects. Contribution of working group II to the fifth assessment report of the intergovernmental panel on climate change. Cambridge University Press, Cambridge and New York

Dudgeon D, Arthington AH, Gessner MO, Kawabata ZI, Knowler DJ, Lévêque C, Naiman RJ, Prieur-Richard A-H, Soto D, Stiassny MLJ, Sullivan CA (2006) Freshwater biodiversity: importance, threats, status and conservation challenges. Biol Rev 81:163-182

Dugan P, Sugunan VV, Welcomme RL, Bene C, Brummett RE, Beveridge MCM, Kofi A, Amerasinghe U, Arthington A, Blixt M, Chimatiro S, Katiha P, King J, Kolding J, Khoa SN, Turpie J (2007) Inland fisheries and aquaculture. In: Molden D (ed) Water 
for food, water for life: a comprehensive assessment of water management in agriculture. Earth scan and International Water Management Institute, pp 459-483

DWAF (Department of Water Affairs and Forestry) (1996) Water quality guidelines, volume 7, Aquatic ecosystems. Department of Water Affairs and Forestry, Republic of South Africa. https:// www.capetown.gov.za/en/CSRM/Documents/Aquatic_Ecosy stems_Guidelines.pdf. Accessed 2 Feb 2016

EC (European Commission) (2003) Guidance document No 10. Rivers and Lakes-typology, reference conditions and classification systems. European Commission, Brussel

Engloner A, Vargha M, Báldi A, Józsa J (eds) (2019) Hungarian water research programme: challenges and research tasks. Centre for Ecological Research, Tihany

Ericson JP, Vörösmarty CJ, Dingman SL, Ward LG, Meybeck M (2006) Effective sea-level rise in deltas. Sources of change and human-dimension implications. Glob Planet Change 50:63-82

Finlayson CM, D'Cruz R (2005) Inland water systems. In: Hassan $\mathrm{H}$, Scholes R, Ash N (eds) Ecosystems and human well-being: current state and trends: findings of the conditions and trends Working Group. Millennium Ecosystem Assessment. Island Press, Washington D.C

Frey D (1975) Biological integrity of water: an historical perspective. In: Ballentine RK, Guarraia LJ (eds) The integrity of water. US EPA, Washington, DC, pp 127-139

Grill G, Lehner B, Thieme M, Geenen B, Tickner D, Antonelli F, Babu S, Borrelli P, Cheng L, Crochetiere H, Ehalt Macedo H, Filguerias R, Goichot M, Higgins J, Hogan Z, Lip B, McClain ME, Meng J, Mulligan M, Nilsson C, Olden JD, Opperman JJ, Petry P, Reidy Liermann C, Sáenz L, Slinas-Rodriguez S, Schelle P, Schmitt RJP, Snider J, Tan F, Tockner K, Valdujo PH, van Soesbergen A, Zarfl C (2019) Mapping the world's free-flowing rivers. Nature 569:215-221

Guo L, Li Z (2003) Effects of nitrogen and phosphorus from fish cage-culture on the communities of a shallow lake in middle Yangtze River basin of China. Aquaculture 226:201-212

Hallare AV, Factor PA, Santos EK, Hollert H (2009) Assessing the impact of fish cage culture on Taal lake (Philippines) water and sediment quality using the zebrafish embryo Assay. Philipp J Sci 138:91-104

Hering D, Borja A, Carstensen J, Carvalho L, Elliott M, Feld CK, Heiskanen A-S, Johnson RK, Moe J, Pont D, LycheSolheim A, van de Bund W (2010) The European water framework directive at the age of 10: a critical review of the achievements with recommendations for the future. Sci Total Environ 408:407-419

Hinck JE, Blazer VS, Schmitt CJ, Papoulias DM, Tillitt DE (2009) Widespread occurrence of intersex in black basses (Micropterus spp.) from US rivers, 1995-2004. Aquat Toxicol 95:60-70

IPBES (2019) Summary for policymakers of the global assessment report on biodiversity and ecosystem services of the intergovernmental science-policy platform on biodiversity and ecosystem services. In: Díaz S, Settele J, Brondízio ES, Ngo HT, Guèze M, Agard J, Arneth A, Balvanera P, Brauman KA, Butchart SHM, Chan KMA, Garibaldi LA, Ichii K, Liu J, Subramanian SM, Midgley GF, Miloslavich P, Molnár Z, Obura D, Pfaff A, Polasky S, Purvis A, Razzaque J, Reyers B, Chowdhury R, Shin YJ, Visseren-Hamakers IJ, Willis KJ, Zayas CN (eds) IPBES secretariat. Bonn, Germany

Jackson CR (2006) Wetland hydrology. In: Batzer DP, Sharitz RR (eds) Ecology of freshwater and estuarine wetlands. University of California Press, Berkeley, pp 43-81

Jobling S, Nolan M, Tyler CR, Brighty G, Sumpter JP (1998) Widespread sexual disruption in wild fish. Environ Sci Technol $32: 2498-2506$
Karvonen A, Rintamäki P, Jokela J, Valtonen ET (2010) Increasing water temperature and disease risks in aquatic systems: climate change increases the risk of some, but not all, diseases. Int $\mathrm{J}$ Parasitol 40:1483-1488

Kennedy VS (2004) Thermal pollution. Encyclopedia of energy, vol 6. Elsevier, Amsterdam, p 16

Kirillin G, Shatwell T, Kasprzak P (2013) Consequences of thermal pollution from a nuclear plant on lake temperature and mixing regime. J Hydrol 496:47-56

Kirschke S, Avellán T, Bärlund I, Bogardi JJ, Carvalho L, Chapman D, Dickens CWS, Irvine K, Lee SB, Mehner T, Warner S (2020) Capacity challenges in water quality monitoring: understanding the role of human development. Environ Monit Assess 192:298

Kummu M, de Moel H, Ward PJ, Varis O (2011) How close do we live to water? A global analysis of population distance to freshwater bodies. PLoS ONE 6:e20578

Kundzewicz ZW, Mata LJ, Arnell NW, Döll P, Jimenez B, Miller K, Oki T, Sen Z, Shiklomanov I (2008) The implications of projected climate change for freshwater resources and their management. Hydrol Sci J 53:3-10

Kura Y, Revenga C, Hocino E, Mock G (2004) Fishing for answers: making sense of the global fish crisis. World Resources Institute, Washington, D.C.

Lehner B, Liermann CR, Revenga C, Vörösmarty C, Fekete B, Crouzet P, Döll P, Endejan M, Frenken K, Magome J, Nilsson C, Robertson JC, Rödel R, Sindorf N, Wisser D (2011) High- resolution mapping of the world's reservoirs and dams for sustainable riverflow management. Front Ecol Environ 9:494-502

Lindenmayer DB, Likens GE (2010) Effective ecological monitoring. CSIRO Publishing, Melbourne

Malmqvist B, Rundle S (2002) Threats to the running water ecosystems of the world. Environ Conserv 29:134-153

Matthews JH, Wickel AJ (2009) Embracing uncertainty in freshwater climate change adaptation: a natural history approach. Clim Dev $1: 269-279$

Matthews JH, Le Quesne T, Wilby R, Pegram G, Von der Heyden C, Wickel AJ, Hartmann J, McSweeney C, Guthrie C, Blate G, Kimura de Frietas G, Levine E (2009) Flowing forward: informing climate-resilient biodiversity conservation and integrated water resources management decisions. The World Bank, Washington, D.C.

Matthews JH, Forslund A, McClain ME, Tharme RE (2014) More than the fish: environmental flows for good policy and governance, poverty alleviation and climate adaptation. Aquat Procedia $2: 16-23$

MEA (2005) Ecosystems and human well-being: synthesis. Island Press, Washington, D.C.

Meyer L, Du Preez L, Bonneau E, Héritier L, Quintana MF, Valdéon G, Sadaoui A, Kechemir-Issad N, Palacios C, Verneau O (2015) Parasite host-switching from the invasive American red-eared slider, Trachemys scripta elegans, to the native Mediterranean pond turtle, Mauremys leprosa, in natural environments. Aquat Invasions 10:79-91

Mills LJ, Chichester C (2005) Review of evidence: are endocrinedisrupting chemicals in the aquatic environment impacting fish populations? Sci Total Environ 343:1-34

Milly PCD, Betancourt J, Falkenmark M, Hirsch RM, Kundzewicz ZW, Lettenmaier DP, Stouffer RJ (2008) Stationarity is dead: whither water management? Science 319:573-574

Naiman RJ, Bilby RE (1998) River ecology and management: lessons from the Pacific Coastal Eco region. Springer, New York

Nakamura K, Tockner K, Amano K (2006) River and wetland restoration: lessons from Japan. Bioscience 56:419-429

Neill C, Deegan LA, Thomas SM, Haupert CL, Krusche AV, Ballester MVR, Victoria R (2006) Deforestation alters the hydraulic and 
biogeochemical characteristics of small lowland Amazonian streams. Hydrol Process 20:2563-2580

Nel JL, Roux DJ, Abell R, Ashton PJ, Cowling RM, Higgins JV, Thieme M, Viers JH (2009) Progress and challenges in freshwater conservation planning. Aquatic conservation: marine and freshwater. Ecosystems 19:474-485

Nilsson C, Reidy CA, Dynesius M, Revenga C (2005) Fragmentation and flow regulation of the World's large river systems. Science 308:405-408

OECD (Organisation for Economic Co-operation and Development) (1993) OECD core set of indicators for environmental performance reviews. OECD Environment Monographs No. 83. OECD, Paris, France

Olden JD, Kennard MJ, Pusey BJ (2008) Species invasions and the changing biogeography of Australian freshwater fishes. Glob Ecol Biogeogr 17:25-37

Opperman J, Grill G, Hartmann J (2015) The power of rivers: finding balance between energy and conservation in hydropower development. The Nature Conservancy, Washington, D.C.

Palaniappan M, Gleick PH, Allen L, Cohen MJ, Christian-Smith J, Smith C, Ross N (2010) Clearing the waters: a focus on water quality solutions. United Nations Environment Program, p 91

Palmer MA, Menninger HL, Bernhardt E (2010) River restoration, habitat heterogeneity and biodiversity: a failure of theory or practice? Freshw Biol 55:205-222

Peterson EE, Sheldon F, Darnell R, Bunn SE, Harch BD (2011) A comparison of spatially explicit landscape representation methods and their relationship to seasonal stream conditions. Freshw Biol 56:590-610

Poff NL, Allan JD, Bain MB, Karr JR, Prestegaard KL, Richter BD, Sparks RE, Stromberg JC (1997) The natural flow regime. Bioscience 47:769-784

Poff NL, Richter BD, Arthington AH, Bunn SE, Naiman RJ, Kendy E, Acreman M, Apse C, Bledsoe BP, Freeman MC, Henriksen J, Jacobsen RB, Kennen JG, Merritt DM, O'Keeffee JH, Olden JD, Rogers K, Tharme RE, Warner A (2010) The ecological limits of hydrologic alteration (ELOHA): a new framework for developing regional environmental flow standards. Freshw Biol 55:147-170

Postel S, Richter B (2003) Rivers for life: managing water for people and nature. Island Press, Washington, D.C.

Rahel FJ (2000) Homogenization of fish faunas across the United States. Science 288:854-856

Richter BD, Postel S, Revenga C, Scudder T, Lehner B, Churchill A, Chow M (2010) Lost in development's shadow: the downstream human consequences of dams. Water Altern 3:14-42

Riis T, Olesen B, Clayton JS, Lambertini C, Brix H, Sorrell BK (2012) Growth and morphology in relation to temperature and light availability during the establishment of three invasive aquatic plant species. Aquat Bot 102:56-64

Rockström J, Steffen W, Noone K, Persson A, Chapin FS, Lambin EF, Lenton TM, Scheffer M, Folke C, Schellnhuber HJ, Nykvist B, de Wit C, Hughes T, van der Leeuw S, Rodhe H, Sörlin S, Snyder PK, Costanza R, Svedin U, Falkenmark M, Karlberg L, Corell RW, Fabry VJ, Hansen J, Walker B, Liverman D, Richardson K, Crutzen P, Foley J (2009) A safe operating space for humans. Nature 461:472-475

Rosenberg DM, Berkes F, Bodaly RA, Hecky RE, Kelly CA, Rudd JW (1997) Large-scale impacts of hydroelectric development. Environ Rev 5:27-54

Rosenberg DM, McCully P, Pringle CM (2000) Global-scale environmental effects of hydrological alterations: introduction. Bioscience 50:746-751

Rosenzweig C, Karoly D, Vicarelli M, Neofotis P, Wu Q, Casassa G, Menzel A, Root TL, Estella N, Seguin B, Tryjanowski P, Chunzen L, Rawlins S, Imeson A (2008) Attributing physical and biological impacts to anthropogenic climate change. Nature 453:353-357

Schofield NJ, Davies PE (1996) Measuring the health of our rivers. Water Melb Then Artarmon 23:39-43

Settele J, Scholes R, Betts R, Bunn S, Leadley P, Nepstad D, Overpeck JT, Taboada MA (2014) Terrestrial and inland water systems. In: Field CB, Barros VR, Dokken DJ, Mach KJ, Mastrandrea MD, Bilir TE, Chatterjee M, Ebi KL, Estrada YO, Genova RC, Girma B, Kissel ES, Levy AN, MacCracken S, Mastrandrea PR, White LL (eds) (2014) Climate change 2014: impacts, adaptation, and vulnerability. Part A: global and sectoral aspects. Contribution of working group II to the fifth assessment report of the intergovernmental panel on climate change. Cambridge University Press, Cambridge and New York, pp 271-359

Shumilova O, Tockner K, Thieme M, Koska A, Zarfl C (2018) Global water transfer megaprojects: a potential solution for the waterfood-energy nexus? Front Environ Sci 6:150

Smith KG, Barrios V, Darwall WRT, Numa C (eds) (2014) The status and distribution of freshwater biodiversity in the Eastern Mediterranean. IUCN, Cambridge

Spikmans F, van Tongeren T, van Alen T, van der Velde G, den Camp $\mathrm{H}$ (2013) High prevalence of the parasite Sphaerothecum destruens in the invasive topmouth gudgeon Pseudorasbora parva in the Netherlands, a potential threat to native freshwater fish. Aquat Invasions 8:355-360

Strayer DL (2010) Alien species in fresh waters: ecological effects, interactions with other stressors, and prospects for the future. Freshw Biol 55:152-174

Strayer DL, Dudgeon D (2010) Freshwater biodiversity conservation: recent progress and future challenges. J N Am Benthol Soc 29:344-358

Tharme RE (2003) A global perspective on environmental flow assessment: emerging trends in the development and application of environmental flow methodologies for rivers. River Res Appl 19:397-441

Tockner K (2019) Oral communication at the science panel session of the 3rd Budapest Water Summit. http://www.watersecurityne twork.org/robert-varady-participates-in-the-third-budapest-water -forum/?LMCL $=$ HFAd4b. Accessed 18 Jan 2020

Trenberth KE, Smith L, Qian T, Dai A, Fasullo J (2007) Estimates of the global water budget and its annual cycle using observational and model data. J Hydrometeorol 8:758-769

UN Environment (2018) A Framework for freshwater ecosystem management. UN Environment, Nairobi

UNCBD (2011) Strategic plan for biodiversity 2011-2020 including Aichi biodiversity targets. UNCBD, Montreal

UNGA (United Nations General Assembly) (2015) Transforming our world: the 2030 agenda for sustainable development. Resolution adopted by the General Assembly on 25 September 2015. http://www.un.org/ga/search/view_doc.asp?symbol=A/ RES/70/1\&Lang $=$ E. Accessed 18 Feb 2016

UN-Water (2018) SDG 6 Synthesis report 2018 on water and sanitation. UN-Water, Geneva

UN-Water (United Nations inter-agency mechanism on all freshwater related issues, including sanitation) (2011) Policy brief: water quality. http://www.unwater.org/fileadmin/user_upload/unwater_ new/docs/waterquality_policybrief.pdf. Accessed 23 Feb 2016

US EPA (US Environmental Protection Agency) (2006) Concepts and approaches for the bioassessment of non-wadeable streams and rivers. EPA/600/R/06/127. http://nepis.epa.gov/Exe/ZyPDF .cgi/600006KV.PDF?Dockey=600006KV.PDF. Accessed 02 Feb 2016

US EPA (US Environmental Protection Agency) (2011) A Primer on using biological assessments to support water quality management, U.S. Environmental Protection Agency, Washington, DC, EPA 810-R-11-01. http://water.epa.gov/scitech/swguidance/ 
standards/criteria/aqlife/biocriteria/upload/primer_update.pdf Accessed 02 Feb 2016

van Vliet MTH, Yearsley JR, Ludwig F, Vogele S, Lettenmaier DP, Kabat P (2012) Vulnerability of US and European electricity supply to climate change. Nat Clim Change 2:676-681

Vörösmarty CJ (2013) Humans in the anthropocene: masters of integrated water management or bulls in the China shop? Keynote lecture, Budapest Water Summit, 9th October 2013. Budapest, Hungary. http://www.budapestwatersummit.hu/budapest-water -summit/summit-plenavy/. Accessed 10 Mar 2016

Vörösmarty CJ, Sahagian D (2000) Anthropogenic disturbance of the terrestrial water cycle. Bioscience 50:753-765

Vörösmarty CJ, Meybeck M, Fekete B, Sharma K, Green P, Syvitski JP (2003) Anthropogenic sediment retention: major global impact from registered river impoundments. Glob Planet Change 39:169-190

Vörösmarty CJ, Lettenmaier D, Leveque C, Meybeck M, Pahl-Wostl C, Alcamo J, Cosgrove W, Grassl H, Hoff H, Kabat P, Lansigan F, Lawford R, Naiman R (2004) Humans transforming the global water system. EOS Trans Am Geophys Union 85:509-514

Vörösmarty CJ, McIntyre PB, Gessner MO, Dudgeon D, Prusevich A, Green P, Glidden S, Bunn SE, Sullivan CA, Reidy Liermann C, Davies PM (2010) Global threats to human water security and river biodiversity. Nature 467:555-561

Wallace JS, Acreman MC, Sullivan CA (2003) The sharing of water between society and ecosystems: from conflict to catchment-based co-management. Philos Trans R Soc Lond Ser B Biol Sci 358:2011-2026

Ward JV (1989) The four-dimensional nature of lotic ecosystems. J N Am Benthol Soc 8:2-8

WCD (World Commission on Dams) (2000) Dams and development. A new framework for decision-making. Earthscan Publications Ltd, London

WHO (World Health Organization) (2011) Guidelines for drinkingwater quality. WHO Press, Geneva. http://apps.who.int/iris/bitst ream/10665/44584/1/9789241548151_eng.pdf. Accessed 10 Mar 2016

Winder M, Schindler DE (2004) Climatic effects on the phenology of lake processes. Glob Change Biol 10:1844-1856

Wright JF (1995) Development and use of a system for predicting macroinvertebrates in flowing waters. Aust J Ecol 20:181-197

WWAP (2017) The United Nations world water development report 2017. Wastewater: the untapped resource. UNESCO, Paris

Zarfl C, Lumsdon AE, Berlekamp J, Tydecks L, Tockner K (2015) A global boom in hydropower dam construction. Aquat Sci 77:161-170

Zhang KM, Wen ZG (2008) Review and challenges of policies of environmental protection and sustainable development in China. J Environ Manag 88:1249-1261 